\title{
The physical and chemical characteristics of marine primary organic aerosol: a review
}

\author{
B. Gantt and N. Meskhidze \\ Department of Marine, Earth, and Atmospheric Sciences, North Carolina State University, Raleigh, North Carolina, USA
}

Correspondence to: N. Meskhidze (nmeskhidze@ncsu.edu)

Received: 19 July 2012 - Published in Atmos. Chem. Phys. Discuss.: 23 August 2012

Revised: 5 March 2013 - Accepted: 24 March 2013 - Published: 18 April 2013

\begin{abstract}
Knowledge of the physical characteristics and chemical composition of marine organic aerosols is needed for the quantification of their effects on solar radiation transfer and cloud processes. This review examines research pertinent to the chemical composition, size distribution, mixing state, emission mechanism, photochemical oxidation and climatic impact of marine primary organic aerosol (POA) associated with sea-spray. Numerous measurements have shown that both the ambient mass concentration of marine POA and size-resolved organic mass fraction of sea-spray aerosol are related to surface ocean biological activity. Recent studies have also indicated that fine mode (smaller than $200 \mathrm{~nm}$ in diameter) marine POA can have a size distribution independent from sea-salt, while coarse mode aerosols (larger than $1000 \mathrm{~nm}$ in diameter) are more likely to be internally mixed with sea-salt. Modelling studies have estimated global submicron marine POA emission rates of $\sim 10 \pm 5 \mathrm{Tg} \mathrm{yr}^{-1}$, with a considerable fraction of these emissions occurring over regions most susceptible to aerosol perturbations. Climate studies have found that marine POA can cause large local increases in the cloud condensation nuclei concentration and have a non-negligible influence on model assessments of the anthropogenic aerosol forcing of climate. Despite these signs of climate-relevance, the source strength, chemical composition, mixing state, hygroscopicity, cloud droplet activation potential, atmospheric aging and removal of marine POA remain poorly quantified. Additional laboratory, field, and modelling studies focused on the chemistry, size distribution and mixing state of marine POA are needed to better understand and quantify their importance.
\end{abstract}

\section{Introduction}

One of the largest uncertainties of the aerosol-cloud system is the background concentration of natural aerosols, especially over clean marine regions where cloud condensation nuclei $(\mathrm{CCN})$ concentration ranges from less than 100 to $\sim 500 \mathrm{~cm}^{-3}$ (Andreae and Rosenfeld, 2008). As estimates of anthropogenic forcing are based on a pre-industrial atmosphere composed mainly of natural aerosols, the representation of marine aerosols in climate models strongly influences the predictions of current and future climate effects of anthropogenic aerosols. The lower bounds of aerosol number concentration over the oceans (from 0 to $40 \mathrm{~cm}^{-3}$ ) often prescribed in global climate models can vary the simulated indirect effect of anthropogenic aerosols by as much as $80 \%$ (Hoose et al., 2009).

Marine aerosols can be derived from both primary and secondary processes. Sea-salt aerosols, with estimated global emissions of 2000-10000 $\mathrm{Tg} \mathrm{yr}^{-1}$ (when limited to diameters less than $20 \mu \mathrm{m}$ ), were proposed to be a major component of primary marine aerosol mass over the regions where wind speeds are high and/or other aerosol sources are weak (O'Dowd et al., 1997; Murphy et al., 1998; Bates et al., 2005; de Leeuw et al., 2011). Dimethyl sulfide (DMS)-derived sulfate was thought to be the key precursor to secondary marine aerosol mass over biologically-productive regions (Shaw, 1983; Charlson et al., 1987). Several recent reviews addressing marine aerosols focused on their production and physicochemical characteristics (Lewis and Schwartz, 2004; O'Dowd and de Leeuw, 2007; de Leeuw et al., 2011), contribution to marine boundary layer (MBL) CCN budget (Quinn and Bates, 2011), role for cloud-precipitation interactions (Andreae and Rosenfeld, 2008), and feedbacks within the 
Earth system (Carslaw et al., 2010). Overall, these studies suggest that ocean-derived aerosols in general and sea-spray aerosols (SSA) in particular can influence the radiation balance of the atmosphere, modify cloud microphysical properties and participate in chemical transformations in remote marine and coastal regions. Despite many open questions related to the production mechanism, most studies agree that a large number of SSA particles are produced through bursting bubbles and involve both jet and film drops. Recent studies also suggested that the definition of SSA be expanded to include both sea-salt and primary organic matter of marine origin.

It has been known for quite some time that large amounts of organic matter can be incorporated in submicron SSA (Blanchard, 1964). However, the mixing state of sea-salt and organics, chemical fractionation of the organic matter, and the production mechanism leading to enrichment (relative to seawater) of organics in SSA is not well characterised. There have been numerous measurements of the organic aerosol concentration in the clean marine areas, with a reported average surface concentration of $\sim 0.5$ and $\sim 0.2 \mu \mathrm{g} \mathrm{C} \mathrm{m}{ }^{-3}$ in the Northern and Southern Hemisphere, respectively (Duce, 1978; Penner, 1995). As these concentrations are well below that of rural continental and urban regions, relatively little attention has been devoted to the formation processes, chemical composition and physical properties of marine organic aerosols. There are two well established production mechanisms for ocean-derived organic aerosol: (1) bubbles produced by breaking waves that scavenge surface-active organic matter and other materials (e.g., bacteria, viruses and detritus) during their ascent and inject it into the atmosphere as marine primary organic aerosols (POA) upon bursting (Blanchard and Woodcock, 1957; Blanchard, 1964; Barger and Garrett, 1970), and (2) oxidation of phytoplankton-emitted volatile organic compounds (VOCs) such as DMS, aliphatic amines, isoprene, and monoterpenes which can form secondary organic aerosols (SOA) (Charlson et al., 1987; Bates et al., 1992; Bonsang et al., 1992; Meskhidze and Nenes, 2006; Yassaa et al., 2008; Facchini et al., 2008a; Gantt et al., 2009; Myriokefalitakis et al., 2010).

This review summarises studies addressing the bulk and size-resolved physiochemical properties, emission mechanisms, potential climate impact and future research needs for improved characterisation of marine POA. Although potentially important for climate impacts, SOA formation from phytoplankton-emitted VOCs (Smoydzin and Glasow, 2007; Meskhidze and Nenes, 2006; Gantt et al., 2009; Myriokefalitakis et al., 2010; Luo and Yu, 2010; Decesari et al., 2011) is not considered. In the current review, we carefully removed studies that were thought to be contaminated by the longrange transport of biomass and fossil fuel combustion products and other terrestrial sources of organic compounds. Nevertheless, we concede that some of our tables/figures summarising marine POA properties may be influenced by ter- restrial and/or secondary organic aerosols as these were not explicitly separated in the original studies.

\section{Chemistry}

\subsection{Bulk aerosol concentrations}

The first detectors of organic matter in SSA used surface active nature of organics to separate them from sea-salt (Blanchard, 1964). Barger and Garrett (1970) collected SSA from the Hawaiian coast on glass fiber filters and determined the concentration of chloroform extractable surface-active organic matter to be 0.7 to $7.9 \mu \mathrm{g} \mathrm{m}^{-3}$, contributing 5 to $15 \%$ of airborne particulate mass. Ship-borne measurements by Barger and Garrett (1976) in the Pacific Ocean near Galapagos Islands using the similar analytical technique were considerably lower, from 0.08 to $4.02 \mu \mathrm{g} \mathrm{m}^{-3}$ with the majority of samples having concentrations much less than $1 \mu \mathrm{g} \mathrm{m}^{-3}$ (the highest value of $4.02 \mu \mathrm{g} \mathrm{m}^{-3}$ was measured off the Pacific coast of Panama). Hoffman and Duce (1974) used the hot persulfate-induced organic matter oxidation method of Menzel and Vaccaro (1964) to measure an organic aerosol concentration in Bermuda ranging from 0.15 to $0.47 \mu \mathrm{g} \mathrm{m}^{-3}$. This was the first of many measurements (summarised in Fig. 1 and Supplement Table S1) of organic aerosol concentrations in "clean marine" conditions having black carbon (BC) concentrations $<0.05 \mu \mathrm{g} \mathrm{m}^{-3}$ (Clarke, 1989). Shank et al. (2012) recently suggested that the $0.05 \mu \mathrm{g} \mathrm{m}^{-3} \mathrm{BC}$ concentration threshold for clean marine conditions may be too high over specific oceanic regions, as MBL organic aerosol and $\mathrm{BC}$ concentrations were positively correlated even at very low $\left(0.02 \mu \mathrm{g} \mathrm{m}^{-3}\right) \mathrm{BC}$ levels. This increases the uncertainty associated with older measurements, as the detection limit (if measured) of BC concentrations was likely higher than this value. At Mace Head, Ireland, the criteria for clean marine conditions include onshore wind direction, $\mathrm{BC}$ concentration $<0.05 \mu \mathrm{g} \mathrm{m}^{-3}$, and total particle number concentration below $700 \mathrm{~cm}^{-3}$ (Rinaldi et al., 2009). Adherence to such strict conditions minimises sampling during incursions of continental pollution (Savoie et al., 2002). We acknowledge that there are no places (especially in the Northern Hemisphere) where a pristine atmosphere without anthropogenic pollution exists (Andreae, 2007), and attempt to report only the instances in which anthropogenic pollution is at a minimum. The upper and lower ranges of observed organic aerosol concentrations in the clean MBL have been determined in two different oceanic locations using an aerosol mass spectrometer (AMS). The upper range of concentrations was found at Mace Head with AMS-derived hourly concentrations of up to $3.8 \mu \mathrm{g} \mathrm{m}^{-3}$ (Ovadnevaite et al., 2011a) from an air mass originating over high biological activity (HBA; [Chl $a$ ] $>1.0 \mathrm{mg} \mathrm{m}^{-3}$ ) waters. The lower range of concentrations was found in the Southeast Pacific, where AMS measurements of the least polluted air showed 


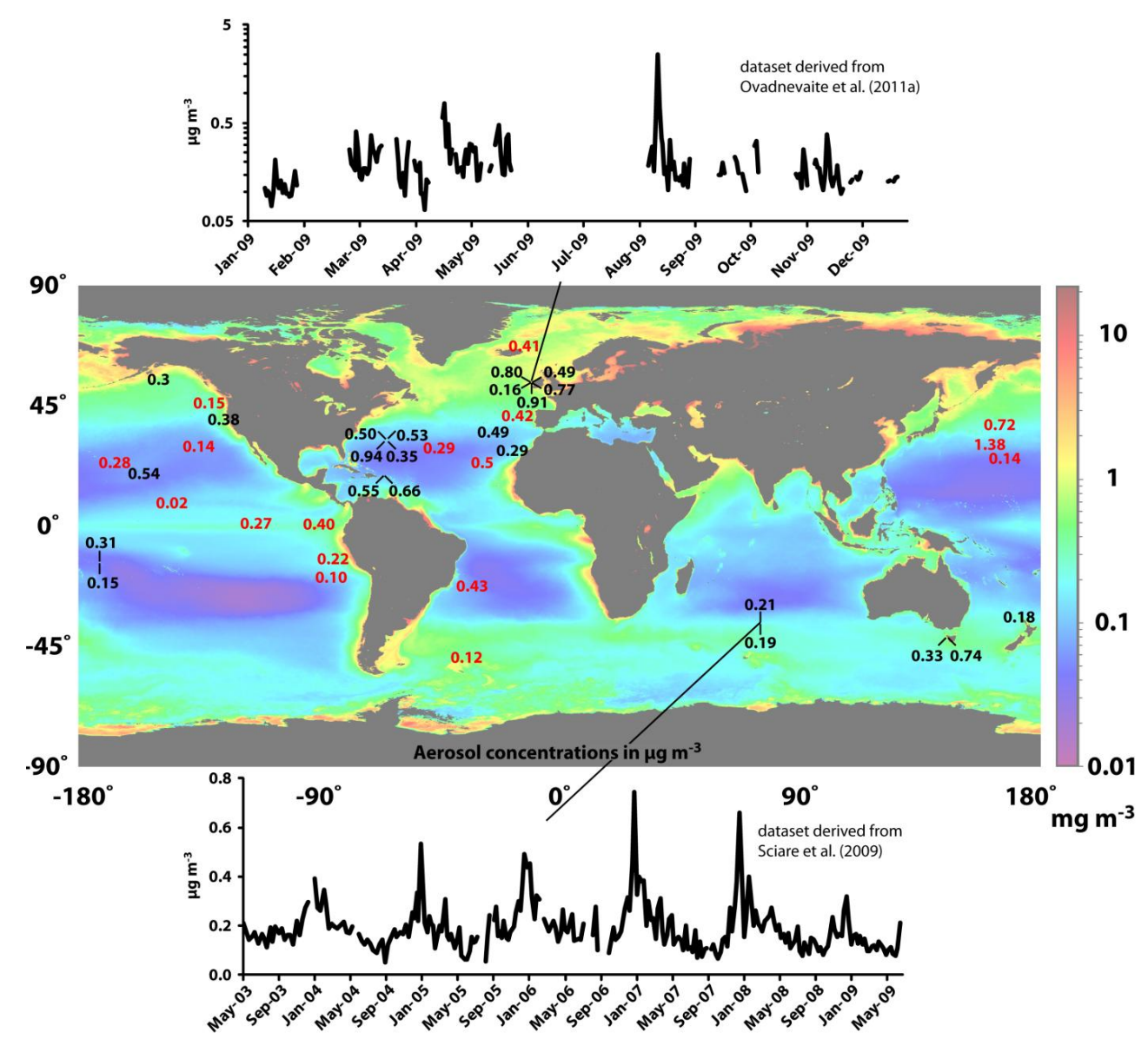

Fig. 1. Climatological (1997-2010) chlorophyll- $a$ concentration $\left(\mathrm{mg} \mathrm{m}^{-3}\right)$ from the Sea-viewing Wide Field-of-view Sensor (SeaWiFS) superimposed with observed organic aerosol concentrations $\left(\mu \mathrm{g} \mathrm{m}^{-3}\right.$ ) averaged from coastal sites (black) and regionally-averaged from ship cruises (red) in clean marine conditions. See Supplement Table S1 for measurement details and references.

an average organic aerosol concentration of $0.01 \mu \mathrm{g} \mathrm{m} \mathrm{m}^{-3}$ (Shank et al., 2012). Long-term measurements shown in Fig. 1 at Mace Head in the North Atlantic Ocean and Amsterdam Island in the Southern Indian Ocean have found that the concentration of organic aerosols of marine origin follow a strong seasonal cycle, with the highest concentrations occurring in the spring/summer and lowest in the winter (Yoon et al., 2007; Sciare et al., 2009). Sciare et al. (2009) hypothesised that the seasonality in marine POA concentrations was due to changes in surface ocean biological productivity, which follows a similar seasonal cycle.

In addition to measurements reporting only marine POA concentrations, several studies have reported an organic/seasalt mass ratio. The organic/sea-salt mass ratio can be a useful parameter for modelling studies, as the marine POA emission rates can be scaled to the model-derived sea-spray emission rate. The first organic/sea-salt mass ratio measurements of sea-spray took place on the east coast of Hawaii. Blanchard (1968) found ratios (given as the mass of surface active film/salt) that varied from 0.3 to 0.7 , while the ratios (given as chloroform-extractable organics/salt) from Barger and Garrett (1970) ranged from 0.07 to 0.14. In Barger and Garrett (1970), the organic/sea-salt mass ratio was observed to increase with increasing wind speed from 1 to $9 \mathrm{~m} \mathrm{~s}^{-1}$; this was thought to be associated with increased transport of adsorbed surface active matter from the sea surface to the atmosphere with higher winds. Hoffman and Duce (1974) reported an organic/sea-salt ratio of 0.01 to 0.19 in Bermuda, with the ratio decreasing with increasing salt concentration. The inverse relationship between the organic material/sea-salt ratio and the total atmospheric salt content observed by Hoffman and Duce (1974) was explained by the shift of particle population to the smaller end of the particle size spectrum with the reduction of the wind speed over the ocean. Measuring only submicron aerosols at Tenerife off the African coast, Putaud et al. (2000) found an average organic/sea-salt ratio $\sim 1$. Long-term measurements of sea-salt and organic aerosols at two coastal sites (Mace Head and Amsterdam Island) show that like the marine POA concentrations, the organic/sea-salt ratio has a seasonal cycle with a maxima in 
the spring-summer and minima in the winter (Yoon et al., 2007; Sciare et al., 2000, 2009). This seasonality is consistent with that of the marine-source low molecular weight (LMW) fatty acid/sea-salt ratio in the North Pacific Ocean (Fang et al., 2002; Mochida et al., 2002). O'Dowd et al. (2008) found that the organic mass fraction of SSA $\left(\mathrm{OM}_{\mathrm{SSA}}\right)$, defined as the mass ratio of water insoluble organic matter and water insoluble organic matter + sea-salt, had a positive linear relationship with offshore [Chl $a]$ at Mace Head. Generally, past studies show that the average bulk concentration of marine POA and organic/sea-salt ratio in clean marine environments is $0.4 \pm 0.3 \mu \mathrm{g} \mathrm{m}^{-3}$ (mean and standard deviation from Table S1) and 0.1, respectively, with spatiotemporal differences related to surface wind speed and ocean physical and biological state that may result in concentrations and organic/seasalt ratios that are nearly an order of magnitude higher or lower.

\subsection{Bulk aerosol composition}

In light of inconsistencies in definitions of clean marine conditions (Clarke, 1989; Shank et al., 2012), comprehensive chemical characterisation of seawater in conjunction with sea-spray aerosol has become an important tool in indentifying organic aerosols with a marine source. Seawater contains various amounts and types of organic material, a large fraction of which remains uncharacterised (Benner, 2002). The key sources are biological production from the marine ecosystem and terrestrial inputs by rivers and the atmosphere. The organic fraction comprises dissolved and particulate organic matter that can be broadly characterised as lipids, amino and fatty acids, mono- and poly-saccharides, humic substances and phytoplankton cell fragments whose spatial distribution varies with location and season (Benner et al., 1992; Aluwihare et al., 1997; Millero, 2006; Hansell et al., 2009). Wurl et al. (2011) showed that the global concentration of surface active material is related to primary production, with nearshore and high latitude waters having higher concentrations than oligotrophic (very low levels of nutrients) waters. Relative to sea-salt, organic concentration in the subsurface seawater, sea surface microlayer, and seaspray aerosols can be very different, with the organic/seasalt ratio increasing from $\sim 10^{-4}$ in the subsurface water to $\sim 10^{-3}$ in the sea surface microlayer and $\sim 0.1$ (with isolated values up to 1) in the aerosol (see Russell et al., 2010 for summary). This suggests that processes within the water column selectively transport organic matter from the bulk seawater to the surface and then from the ocean surface to the atmosphere. The chemical structure-discriminating transfer of organics from the marine surface during adsorptive bubble separation processes was recently studied in depth (Schmitt-Kopplin et al., 2012). Analysis of the composition of airborne marine organic particles over clean marine regions was similar to that of seawater, showing evidence of carbohydrates (Leck and Bigg, 2005; Facchini et al., 2008b; Russell et al., 2010), amino acids (Leck and Bigg, 1999), lipids (Mochida et al., 2002) and marine microorganisms (Leck and Bigg, 2005). Using a Scanning Transmission X-ray Microscopy with Near-Edge X-ray Absorption Fine Structure (STXM-NEXAFS), Hawkins and Russell (2010) classified marine POA into four chemically distinct types: (1) carboxylic acid-containing polysaccharides, (2) low-solubility polysaccharides, (3) calcareous phytoplankton fragments, and (4) proteinaceous material. Schmitt-Kopplin et al. (2012) reported enrichment (from surface ocean to seaspray aerosol) of homologous series of oxo-fatty acids, hydroxyfatty acids, mono-, di- and tricarboxylic acids, epoxy fatty acids, unsaturated fatty acids, primary and secondary alcohols, sugars, monoterpenes, methyl-branched fatty acids, straight chain fatty acids, methoxy-fatty acids and glycerols. All these biomolecules show high aliphaticity and bear a polar or charged group, providing them with a higher surface activity that enables them to participate in the formation of the organic surface microlayer (Schmitt-Kopplin et al., 2012). As these biomolecules from the surface water leave a specific molecular fingerprint in sea-spray aerosol (SchmittKopplin et al., 2012), the qualitative chemical composition of dissolved and colloidal organic matter in the ocean can be used for source apportionment of organic aerosols in marine environment. Despite a higher degree of specificity, however, currently "identifiable" biomarker compound classes only represent small (less than $25 \%$ ) fraction of the total oceanic organic carbon pool (Bauer, 2002). Once emitted, marine POA can also undergo photochemical and bacterial degradation (aging) leading to structural modification of organic compounds (see Sect. 2.6).

Stable carbon isotopic analysis of marine aerosol samples can provide information that is complementary to and unique from organic biomarker analysis. The value of $\delta^{13} \mathrm{C}$ (given by $\left(R_{\text {sample }} / R_{\text {standard }}-1\right) \times 1000$, where $R$ is the ${ }^{13} \mathrm{C} /{ }^{12} \mathrm{C}$ ratio and the isotope standard is Belemnite from the Little PeeDee formation in South Carolina, Craig, 1953) was shown to be approximately $-20 \pm 2 \%$ o for dissolved organic matter in low- and mid-latitude oceans and approximately $-27 \pm$ $2 \%$ o for organic carbon derived from terrestrial plants (Fry et al., 1998; Boutton, 1991; Michener and Schell, 1994; Bauer, 2002). Beginning with Chesselet (1981), several studies have used the $\delta^{13} \mathrm{C}$ of marine aerosols to differentiate the influence of marine and terrestrial sources of organic aerosol in different locations and seasons (Cachier, 1989; Fang et al., 2002; Turekian et al., 2003; Wang and Kawamura, 2006; Narukawa et al., 2008; Miyazaki et al., 2010, Ceburnis et al., 2011; Kawamura et al., 2012). Limitations to $\delta^{13} \mathrm{C}$ quantitative estimates include ambiguity of oceanic and terrestrial sources in most coastal (and some open ocean) environments and lower $\delta^{13} \mathrm{C}$ values for polar waters (Bauer, 2002 and references therein). Analysis of the ${ }^{14} \mathrm{C} /{ }^{12} \mathrm{C}$ ratio (Stuiver and Polach, 1977; Reimer et al., 2004) was also used for quantification of marine $\left(\Delta^{14} \mathrm{C}=-50 \%\right)$, continental $\left(\Delta^{14} \mathrm{C}=100 \%\right)$ and fossil fuel $\left(\Delta^{14} \mathrm{C}=-1000 \%\right.$ ) sources of organic aerosols in 
marine atmosphere (Ceburnis et al., 2011). Due to its greater dynamic range $\left(>1000 \%\right.$ o ${ }^{14} \mathrm{C}$ may potentially be a more sensitive source tracer than ${ }^{13} \mathrm{C}$. Using both ${ }^{13} \mathrm{C}$ and ${ }^{14} \mathrm{C}$ isotope analysis for chemical quantification of the organic matter in seawater and marine aerosols, several studies have shown that ocean biological activity can considerably influence marine organic aerosol composition. Over the Sargasso Sea with upwind fetch of thousands of kilometres of low biological activity (LBA, $[\mathrm{Chl} a]<0.2 \mathrm{mg} \mathrm{m}^{-3}$ ) waters, Chesselet et al. (1981) and Turekian et al. (2003) found that oceanderived organic aerosols made a minor contribution (up to $20 \%$ and $38 \%$, respectively) to the total organic aerosol mass concentration. On the other hand, ocean-derived carbon accounted for $45 \%$ of total organic carbon mass in the highArctic boundary layer aerosols (Narukawa et al., 2008), 46$72 \%$ for HBA ( $8-36 \%$ for LBA waters) of the western North Pacific Ocean (Miyazaki et al., 2010), and up to $80 \%$ of the total organic aerosol mass concentration at Mace Head, Ireland (Ceburnis et al., 2011) with a $23000 \mathrm{~km}$ upwind fetch over HBA waters of the North Atlantic Ocean.

Other recent studies have employed technologies such as the AMS to determine unique spectroscopic properties of marine POA. Using an aerosol time-of-flight mass spectrometer in the Indian Ocean, Gaston et al. (2011) detected magnesium $(\mathrm{Mg})$-type particles whose source was suggested to be organic material in the ocean. These particles were strongly correlated to fresh sea-salt and atmospheric concentrations of DMS, and weakly correlated to surface [Chl $a$ ] (Gaston et al., 2011). In the Arctic, Orellana et al. (2011) found that marine-source organic microgels stabilized by $\mathrm{Ca}^{2+}$ ionic bonds and identifiable by staining with chlortetracycline were a major contributor to $\mathrm{CCN}$ concentrations. Because they are independent of terrestrial and anthropogenic proxies such as black carbon and radon, these spectroscopic, isotopic and microscopic analyses of organic aerosols are valuable tools in identifying a marine source and should supplement field measurements of organic mass concentrations.

\subsection{Size-resolved aerosol concentrations}

With improvements and increased abundance of aerosol instrumentation, a more comprehensive understanding of the spatial distribution and temporal variation in marine POA concentrations has emerged. The mass contribution of organic matter in sea-spray has been repeatedly shown to vary considerably with aerosol size. As the size of an aerosol is important for its heterogeneous chemistry, atmospheric lifetime and CCN activity, size-resolved concentrations of specific aerosol types give valuable information in determining their climatic impact. Despite having low bulk concentrations as described in Sect. 2.1, marine POA can have a high climatic impact due to their relatively large mass (and number depending on the mixing state) concentration in the accumulation mode (diameters between $\sim 50$ and $300 \mathrm{~nm}$ ) compared to other aerosols present in remote MBL. Beginning with the

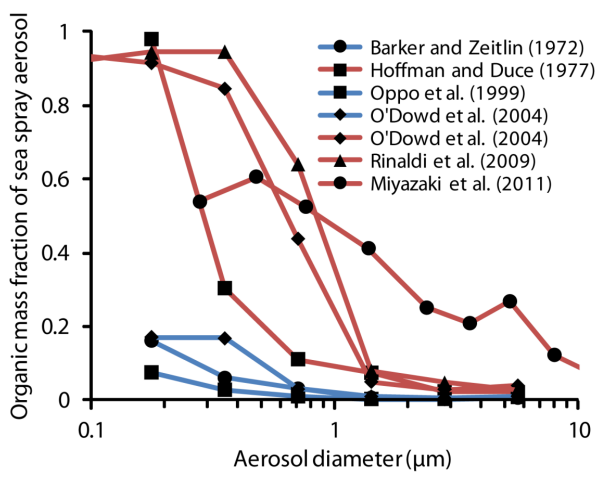

Fig. 2. Size-resolved organic mass fraction of sea-spray aerosol measured in clean marine conditions. The blue lines represent low biological activity periods and red lines represent high biological activity periods.

Barker and Zeitlin (1972) and Hoffman and Duce (1977) use of cascade impactors to determine size-resolved SSA chemistry, most studies have found that the organic mass fraction of SSA and aerosol diameter are inversely proportional (see Fig. 2). Oppo et al. (1999) developed a spray drop adsorption model to describe these observations by quantifying the volume of an organic film surrounding SSA relative to the total aerosol volume. An inverted micelle model of Ellison et al. (1999) described the organic film surrounding a seasalt/water core, and used a geometric argument to show that the organic film/total aerosol mass ratio is an inverse function of SSA diameter. O'Dowd et al. (2004) suggested that the organic fraction of accumulation mode aerosol mass concentration over the North Atlantic Ocean is related to ocean biological productivity, with organics making up more than $60 \%$ of SSA mass during HBA periods and less than $20 \%$ during LBA periods. Subsequent measurements by Rinaldi et al. (2010) and Miyazaki et al. (2010) also revealed progressively larger contributions of organic compounds to total SSA mass with decreasing particle size and increasing surface ocean biological activity. These measurements are summarised in Fig. 2, with the high and low biological activity measurement periods denoted with red and blue lines, respectively.

In bubble bursting experiments replicating nascent SSA emission, Keene et al. (2007) and Facchini et al. (2008b) found that $\sim 80 \%$ of the mass at the smallest (geometric mean diameter of $130 \mathrm{~nm}$ and aerodynamic diameter between 125 and $250 \mathrm{~nm}$ for Keene et al. (2007) and Facchini et al. (2008b), respectively) aerosol sizes was organic. These high organic mass fractions for small SSA sizes were found in both LBA and HBA waters, with Long et al. (2011) proposing a Langmuir functional relationship between the organic mass fraction and $[\mathrm{Chl} a]$. High organic mass fractions in accumulation mode SSA have not been found in all bubble-bursting experiments. Using the hygroscopic growth of SSA to determine the presence of organics 
(see Sect. 2.5), Sellegri et al. (2008), Modini et al. (2010a, b) and Fuentes et al., 2010, 2011) all found organic mass fractions $<40 \%$. Specifically, Modini et al. (2010a), using a Volatility Hygroscopicity-Tandem Differential Mobility Analyzer (HTDMA), found that the organic volume fraction of aerosols produced from bubble bursting of seawater off the Australian coast was $8 \pm 6 \%$ for aerosols between 71 and $77 \mathrm{~nm}$ in diameter with little variability in the organic volume fraction for aerosol with diameters between 38 and $173 \mathrm{~nm}$. Using laboratory grown phytoplankton monocultures to generate exudate at unnaturally high concentrations, Fuentes et al. (2011) estimated (through HTDMA measurements) a submicron aerosol organic volume fraction ranging from 8 to $37 \%$. Sellegri et al. (2008) also explored the effects of air currents (with velocity of around $1 \mathrm{~m} \mathrm{~s}^{-1}$ ) on the normalised aerosol size distribution. The bubbles were artificially broken by the wind blowing into the surfactant foam generated by the large pore sintered glass filter in synthetic seawater. The results obtained by Sellegri et al. (2008) show that in the presence of surfactants, wind stress significantly increases the production of aerosols in the $300-350 \mathrm{~nm}$ diameter size range. Such amplification of the mode centered at $300 \mathrm{~nm}$ in diameter was explained by the forced rupture of the bubbles before they had time to drain, thin out and naturally burst (Sellegri et al., 2006). Currently, it is unclear whether the contradictory results from bubble bursting experiments are due to differences in bubble-production/sea spray aerosol measurement techniques or seawater composition, suggesting the need for aerosol measurements by different research groups to be conducted under the controlled environmental conditions using the same seawater.

\subsection{Size-resolved aerosol composition}

Recent improvements in single particle measurement techniques such as Near-Edge Absorption X-ray Fine Structure (NEXAFS) spectromicroscopy and transmission electron microscopy (TEM) have shown that aerosol size can have large effect on the chemical composition of marine organic aerosol. Leck and Bigg (2010) report that particles less than $50 \mathrm{~nm}$ in diameter, previously thought to be formed only through nucleation, display characteristics of fragmented aggregates of microcolloids. TEM images of marine aerosols from multiple locations led Leck and Bigg (2008) to conclude that in the size range from 50 to $200 \mathrm{~nm}$ in diameter, sea-salt aerosols are nearly absent and the aggregates of microcolloids and exopolymer secretions are the dominant organic aerosol type. In the size range from 200 to $1000 \mathrm{~nm}$ in diameter, Hawkins and Russell (2010) using NEXAFS analysis showed that marine POA were mostly calcareous phytoplankton fragments and low-solubility polysaccharides. In the supermicron sized particles, Hawkins and Russell (2010) found that marine organic aerosols were mostly composed of carboxylic acid-containing polysaccharides mixed with seasalt aerosol. For northern Pacific SSA in the size range from
500 to $\sim 2500 \mathrm{~nm}$ in diameter, Gaston et al. (2011) reported a number concentration of Mg-type particles (proxy for marine organic aerosols) which peaked at the smallest measured diameter $(500 \mathrm{~nm})$ and decreased with size. This was in contrast to sea-salt, which showed increased number concentration as the aerosol diameter increased from 500 to $1000 \mathrm{~nm}$ before decreasing with size for aerosols $>1000 \mathrm{~nm}$ in diameter (Gaston et al., 2011). The marine-source organic microgels identified by Orellana et al. (2011) as being a major CCN contributor in the Arctic had a number concentration distribution with two modes (a major Aitken mode and very minor accumulation mode) peaked at $\sim 10 \mathrm{~nm}$ and $\sim 175 \mathrm{~nm}$ in diameter. These measurement techniques focused on different aerosol sizes show that marine POA are typically more abundant than sea-salt at smaller aerosol sizes and that their chemical composition changes with size.

\subsection{Aerosol hygroscopicity and volatility}

For marine aerosols, the growth factor (GF, defined as the ratio of wet and dry particle mobility diameters at a given relative humidity (RH) of $90 \%$ unless otherwise stated) and volatility have been used to give the relative contribution of sea-salt, sulfate and organic aerosols. The reference GFs of various marine aerosol chemical components include ammonium sulfate (1.7), ammonium bisulfate (1.8), sea-salt (2.0), water soluble organic matter (WSOM) (1.2), and water insoluble organic matter (WIOM) (1.0) (Cavalli et al., 2004; Swietlicki et al., 2008). In terms of reference volatilities, semi-volatile organic compounds typically volatilize at temperatures $<100^{\circ} \mathrm{C}$, sulfate at $160^{\circ} \mathrm{C}$, and very low volatility organics and sea-salt remaining at $600{ }^{\circ} \mathrm{C}$ (Qian and Mopper, 1996; Spyres et al., 2000; de Leeuw et al., 2007). In a review of GF measurements in multiple environments, Swietlicki et al. (2008) reported that marine environments have a nearly ubiquitous occurrence of aerosols within the morehygroscopic group whose GF is $\sim 1.5$, likely corresponding to a volume ratio of $85 \%$ ammonium bisulfate and $15 \%$ organic compounds (Swietlicki et al., 2008). Relative to the more-hygroscopic (GF $\sim 1.5$ ) group, the highly-hygroscopic (sea-salt) group was less frequently present in the marine environments (Swietlicki et al., 2008). During HBA periods in the North Atlantic Ocean, Cavalli et al. (2004) derived a GF (at $80 \% \mathrm{RH}$ ) of 1.2 for marine aerosols with diameters $<125 \mathrm{~nm}$. Recently, Ovadnevaite et al. (2011b) described a HBA period in the North Atlantic that had a concurrence of low GF $(\sim 1.25)$, high organic mass fraction of submicron aerosols, and high particle mean diameter $(\sim 150 \mathrm{~nm}$ in diameter) relative to periods of high sulfate mass fraction $(\sim 100 \mathrm{~nm}$ in diameter). In addition to biological activity, wind speed also plays a role in the observed growth factor. Nilsson et al. (2001) reported a GF of 2.0 (sea-salt) during high wind speeds $\left(>12 \mathrm{~m} \mathrm{~s}^{-1}\right.$ at a height of 35 metres) and a GF of 1.5 during low winds $\left(<3 \mathrm{~m} \mathrm{~s}^{-1}\right.$ at $\left.35 \mathrm{~m}\right)$. Hultin et al. (2010) found that the 
fraction of HBA North Atlantic sea-spray aerosols that are semi-volatile (evaporated at $300^{\circ} \mathrm{C}$ ) varied by aerosol size, with the highest semi-volatile fraction $(\sim 35 \%)$ occurring with particles $140-150 \mathrm{~nm}$ in diameter. In bubble bursting experiments of seawater off the Australian coast representing nascent sea-spray emissions, Modini et al. (2010a) observed a low semi-volatile (evaporated at temperatures between 200 and $500{ }^{\circ} \mathrm{C}$ ) fraction $(10 \%)$ and little difference with aerosol size in the range of 38 to $173 \mathrm{~nm}$ in diameter. Despite some contradictory results, these GF and volatility measurements have been successfully used to infer the aerosol chemistry at sizes difficult to measure using mass-based methods and have indicated that relative to sea-salt, the amount of organics in SSA increases with biological activity and decreases with wind speed in the climate-relevant 100 to $150 \mathrm{~nm}$ diameter size range.

\subsection{Aging in the clean marine atmosphere}

Photochemical oxidation of organic aerosols in the MBL influences their chemical composition, optical properties and the ability to serve as CCN (Quinn et al., 2006). Aging of marine organic aerosol can also act as a source of reactive oxidants (Zhou et al., 2008) and potentially LMW carbonyl compounds (Zhou and Mopper, 1997) which have important implications for MBL atmospheric chemistry. In general, observations of organic aerosols show an increase in oxygenated groups such as organic hydroxyl and carboxylic acids and a decrease in hydrophobic groups such as alkanes, alkenes and aromatic groups with distance from the source (Maria et al., 2004; Zhang et al., 2007; Gilardoni et al., 2007). However, quantification of the chemical processing of marine POA is often complicated in remote regions because of the presence of condensable organic reaction products from multiple sources (i.e., SOA of marine origin, natural continental, and anthropogenic precursor gases) that can all contribute to an additional mass of organic carbon (Turekian et al., 2003; Quinn et al., 2006). Due to the complex mixture of oceanic and continental precursors, very few studies have attempted to characterise aging of marine POA in clean remote air samples; thus, the variability in marine POA size distributions and lifetime due to photochemical aging remains largely unexplored. Based on the observation that freshly emitted submicron marine POA are almost entirely water insoluble consisting of colloids and aggregates (Facchini et al., 2008 b), but can become more water soluble through atmospheric aging (Rinaldi et al., 2010), several modelling studies have treated atmospheric aging of marine POA in a way similar to that of terrestrial POA with 1.2 day time scale for hydrophobic-to-hydrophilic conversion (Gantt et al., 2012a).

Quantification of the photochemical aging of marine POA is further complicated by the fact that the approaches used to characterise the atmospheric processing of terrestrial organic aerosols are not applicable in the remote marine atmosphere. The atomic $\mathrm{O} / \mathrm{C}$ ratio, a useful proxy for photochemical ag- ing of continental organic aerosol, does not vary significantly in the remote atmosphere where a large fraction of organic hydroxyl groups can be contributed from marine POA emissions (Hawkins et al., 2010). To reveal the sources of organic substances in marine aerosols, a combination of molecular and isotopic approaches was applied to organic aerosols collected over the open ocean (Kawamura and Gagosian, 1987; Fang et al., 2002). Compound-specific $\delta^{13} \mathrm{C}$ analysis of $\mathrm{C}_{2}$ to $\mathrm{C}_{9}$ dicarboxylic acids and some ketoacids showed a general increase in the $\delta^{13} \mathrm{C}$ toward the equator associated with photochemical aging (Wang and Kawamura, 2006). However, while oxalic, malonic, succinic and adipic acids had increases in $\delta^{13} \mathrm{C}$, a similar latitudinal trend was not observed for phthalic, maleic and glyoxylic acids (Wang and Kawamura, 2006). No latitudinal trend was observed in the $\delta^{13} \mathrm{C}$ of saturated dicarboxylic acids for the samples from the Arctic and the Southern Oceans, suggesting minor photochemical aging of marine organics at the lower latitudes (Wang and Kawamura, 2006; Kawamura et al., 2012). Interestingly, during a cruise between Tokyo and Antarctica, two "outliers" of photochemically fresh samples containing considerably higher concentrations of unsaturated fatty acids (indicative of the ocean biogenic sources) were collected near the equator under weak solar radiation conditions (Marty et al., 1979; Wang and Kawamura, 2006). If this finding can be representative of the global ocean, it would suggest a very fast (less than one day) aging of marine POA under intense solar radiation. The short atmospheric lifetime of LMW fatty acids in MBL can then be used as a proxy for the photochemical aging of marine POA.

To overcome the difficulty of using ambient measurements for characterisation of the effect of marine organic aerosol on atmospheric chemistry, several studies have used laboratorygenerated nascent marine aerosols and snow crystals. Direct photolysis of marine POA in fresh nascent aerosols and nitrate photolysis in aged (acidified) aerosols were suggested to be important sources of hydroxyl radical and hydroperoxides in the MBL (Zhou et al., 2008). Irradiation of laboratorygenerated snow-phase organic matter was suggested to lead to the production of LMW carbonyl compounds (formaldehyde and acetaldehyde) at the levels high enough to influence atmospheric chemistry at the polar latitudes (Sumner and Shepson, 1999). In general, it is well established that photochemical degradation of refractory dissolved organic matter in the ocean surface water can lead to LMW carbonyl compounds, including formaldehyde, acetaldehyde, propanal, glyoxal, methylglyoxal, glyoxylic acid and pyruvic acid (Kieber and Mopper, 1987; Kieber et al., 1990; Zhou and Mopper, 1997). Such oxidative chemistry (further enhanced by the presence of nitrate and ozone from pollution) may also occur in deliquesced marine organic aerosols and cloud droplets, upon evaporation of which LMW carbonyl compounds can be released into the atmosphere. Although, calculations by Klippel and Warneck (1980) suggest that oxidation of organic aerosol at concentrations of 2 to 
$5 \mathrm{ng} \mathrm{m}^{-3}$ did not contribute significantly to the overall budget of formaldehyde in the MBL, recent studies indicate that the concentration of organic matter in clean marine air masses can be more than two orders of magnitude higher than that of Klippel and Warneck (1980). Currently, the effect of marine POA on MBL atmospheric chemistry remains poorly defined.

Measurements indicate that the rate of photochemical aging of marine POA during the atmospheric transport is likely controlled by the seawater chemical/biological composition: freshly produced LMW organic compounds can be readily degraded by photochemistry (and microbial activities) while refractory forms of dissolved organic matter may strongly resist photodegradation (Mopper et al., 1991). This was experimentally shown in Zhou et al. (2008) where hydroxyl radical and hydroperoxide production rates in samples from nascent SSA decreased with photon exposure. The interaction between atmospheric conditions (i.e., solar radiation, oxidant levels and temperature) and seawater chemi$\mathrm{cal} /$ biological composition on the atmospheric processing of marine POA are not well understood. Improved quantification of marine POA aging should involve studies in which organic compounds with distinct marine signatures are simultaneously characterised in SSA as well as in bulk, surface and aerosolized seawater.

\section{Physics}

\subsection{Aerosol size distribution}

Concurrent measurements of marine aerosol size distribution and chemical composition have shown that the marine POA number size distribution can be distinct from that of sea-salt. Prior to the development of cascade impactors, the number size distribution of marine organic aerosols could only be approximated as typical aerosol sizing techniques did not include chemistry. Novakov and Penner (1993) made one of the first estimates of the number size distribution by applying the Twomey inversion algorithm (Twomey, 1975) to sizeresolved aerosol mass concentrations measurements from a cascade impactor at a coastal mountain site in Puerto Rico. Novakov and Penner (1993) found that due to their high numbers in the size range between 50 and $200 \mathrm{~nm}$ in diameter, natural organic aerosols likely having a marine source (Novakov et al., 1997) made up a major part of the aerosol number concentration and CCN fraction. Comprehensive characterisation of the size-resolved mass concentrations of marine aerosols at Mace Head, Ireland (Cavalli et al., 2004) showed that concentrations of WIOM for aerosols with diameters $<200 \mathrm{~nm}$ were the highest of any chemical species (i.e., sea-salt, sulfate, ammonium, nitrate, WSOM and BC) measured. The volume size distribution of organic matter (given as soluble organic carbon) in sea-spray aerosol from bubble bursting of LBA waters near Bermuda was relatively con- stant for aerosols below $\sim 2500 \mathrm{~nm}$ in diameter, but reached its highest value at the smallest geometric mean diameter $(130 \mathrm{~nm})$ reported (Keene et al., 2007). The aerosol number size distribution over the North Atlantic changed between the LBA and HBA periods, with the increase in accumulation mode mean diameter and number concentration during the HBA period attributed to the additional marine organic aerosol (O'Dowd et al., 2004; Yoon et al., 2007). de Leeuw et al. (2007) found that the size distribution of marine aerosol number concentration in the 200 to $500 \mathrm{~nm}$ aerosol diameter range was affected by the inlet temperature, with the heated inlet (which at $300^{\circ} \mathrm{C}$ measured mostly sea-salt and very low volatility organics) having a number concentration two orders of magnitude lower than that of the non-heated inlet. The same setup of de Leeuw et al. (2007) showed less than an order of magnitude difference between heated and nonheated inlets when aerosols larger than $1000 \mathrm{~nm}$ in diameter were examined. Russell et al. (2010) found a positive linear relationship between the number mean diameter of $\mathrm{CCN}$ and organic aerosol mass concentration for both the North Atlantic and Arctic, a result consistent with that of Yoon et al. (2007). Ovadnevaite et al. (2011b) reported similar results in an AMS study at Mace Head, finding that periods with high organic mass fractions and low growth factors also had a higher weighted average particle size and increased number concentration in the 100 to $500 \mathrm{~nm}$ diameter range.

The overall increase in the ambient aerosol number concentration associated with marine organics is not consistently reproduced in laboratory measurements of bubble bursting experiments representing nascent SSA emission. Paterson and Spillane (1969) found that the number of aerosols produced by the bursting of a single bubble was dependent on the film pressure of the naturally-occurring surface-active material adsorbed on the surface, with increasing film pressure decreasing the aerosol number. Sellegri et al. (2006) described how the sea-spray number distribution is affected by the presence of the surfactant sodium dodecyl sulphate (SDS, described as a proxy for surfactants found in natural seawater) in the bubble bursting tank. When SDS was added to a tank of synthetic seawater simulating calm conditions, the surfactant caused aerosol number concentrations in the Aitken mode ( $\sim 55 \mathrm{~nm}$ in geometric mean diameter) to increase. In another set of experiments in which SDS was added to the tank simulating low wind speeds, the number concentration of an aerosol size mode centered at $300 \mathrm{~nm}$ in diameter was enhanced relative to experiments without the surfactant. An increase in number concentration from the addition of a surfactant to synthetic seawater was not observed by Zábori et al. (2012), who observed decreasing number concentration for all aerosol sizes $(10$ to $1000 \mathrm{~nm}$ in diameter) with increasing succinic acid concentration. Compared to the bubble bursting experiments of synthetic seawater, Tyree et al. (2007) did not observe any change in accumulation mode geometric mean diameter $(\sim 90 \mathrm{~nm})$ by adding oleic acid to synthetic seawater, but did find that the 
total number concentration increased by $50 \%$. Garrett (1968) also observed a $50 \%$ increase in the number concentration after adding oleic acid to unfiltered seawater, although this increase was not observed when the seawater was filtered through a $0.1 \mu \mathrm{m}$ filter. Adding other organic compounds (and mixtures of compounds) to unfiltered seawater increased the particle production from 33 to $233 \%$ (Garrett, 1968). Adding several different organic compounds to synthetic seawater under consistent experimental conditions using two different bubble generation techniques showed that compared to diffuser-generated bubbles, jet impingement leads to lower number concentration of particles with broader size distribution that shifter toward larger particles (King et al., 2012). The addition of strong organic surfactants did not cause any considerable changes in the aerosol size distribution, but reduced the number concentration at all aerosol sizes (10 to $300 \mathrm{~nm}$ in diameter) likely due to the increase in stability of the surface layer and subsequent decrease in the bubble bursting rate (King et al., 2012). Similarly, Modini et al. (2013) observed that the incremental addition of the soluble surfactant Triton X-100 to artificial seawater had little effect on the aerosol size distribution, but decreased the single bubble aerosol production efficiency by $79 \%$ to $98 \%$. High-speed videography revealed that the increased bubble persistence caused by the soluble surfactant lead to a thinning of the bubble film thickness and may have resulted in a reduction in aerosol production (Modini et al., 2013).

In a study involving phytoplankton monoculturegenerated exudate at unnaturally high concentrations, Fuentes et al. (2010) observed a large $(\sim 100 \%)$ increase in the Aitken mode $(\sim 40 \mathrm{~nm}$ in diameter) aerosol number concentration, and a slight increase in the accumulation mode ( $\sim 250 \mathrm{~nm}$ in diameter) number concentration from the addition of concentrated phytoplankton exudate (especially that of Diatomaceous phytoplankton) to synthetic seawater. This increase in the Aitken mode aerosol number concentration, which was consistent with that of Sellegri et al. (2006), was also observed for unfiltered seawater gathered from HBA tropical Atlantic Ocean waters relative to LBA waters (Fuentes et al., 2010). These laboratory and field studies suggest that the impact of organics in seawater on the physiochemical properties of SSA is often contradictory. The type of organic compound, experimental conditions (bubble generation technique, presence/absence of a foam layer, size of the seawater tank) and environmental conditions (ocean biological activity, wind speed, water temperature, bubble size spectra/dynamics, etc.) have all been shown to play an important role in the interaction between organics and SSA size distribution. Additionally, experimental design likely plays a role in contradictory results reported by different research groups; some of the results may suffer from the use of surrogate and potentially non-representative surfactants, organic contamination of synthetic seawater, and depletion of organic material through bubble scavenging. Of the stud- ies in which the aerosol size was affected by the presence of organic compounds, the largest changes typically occurred in the Aitken and accumulation modes with diameters between $\sim 40-90$ and $\sim 250-300 \mathrm{~nm}$, respectively.

\subsection{Aerosol mixing state}

The mixing state of marine organic aerosols with other aerosol types present in the marine boundary layer (e.g., sea-salt, organic matter, ammonium sulfate, methane sulfonate) was suggested to impact the cloud droplet number concentration over the ocean (O'Dowd et al., 2004). The general understanding of the mixing state of marine organic aerosols has changed with time as more recent studies have taken advantage of advanced analytical techniques involving spectrometers and electron microscopes. Middlebrook et al. (1998) used a particle analysis by laser mass spectrometry (PALMS) to find that Southern Ocean marine organic aerosols greater than $160 \mathrm{~nm}$ in diameter were nearly always found internally mixed with individual sea-salt particles. This result was consistent with the hypothesis of an internal mixture of sea-salt and organic aerosols prevalent in earlier studies (Pueschel and Van Valin, 1974; Hoffman and Duce, 1976; Gershey, 1983; Tseng et al., 1992). However, more recent analyses suggest that some marine organic aerosols and sea-salt may be externally-mixed. Aerosol time-of-flight mass spectrometer measurements in the Indian Ocean showed that marine source Mg-type particles were externally-mixed with sea-salt in the size range between 500 and $2000 \mathrm{~nm}$ in diameter (Gaston et al., 2011). Volatility measurements of sea-spray aerosols up to $230 \mathrm{~nm}$ in diameter produced by bubble bursting experiments with seawater from the biologically-active North Atlantic Ocean showed a decrease in sea-spray particle number when a $300^{\circ} \mathrm{C}$ heated inlet was used relative to an unheated inlet, indicating an external mixture of sea-salt and organics (Hultin et al., 2010). TEM analysis has been used in marine environments to detect both single particles composed of organic matter and bacteria in the absence of sea-salt, as well as sea-salt particles associated with surface active matter (Bigg and Leck, 2001, 2008; Leck et al., 2002; Pósfai et al., 2003; Leck and Bigg, 2005, 2008). The reduction (to near absence) in the frequency of sea-salt visible within aerosols $<200 \mathrm{~nm}$ in diameter from TEM analysis suggests that SSA is an external mixture of sea-salt and organics (with the majority of aerosols being organic) in this size range (Bigg and Leck, 2008). Hawkins and Russell (2010) found that both of the submicron marine organic aerosol types identified using STXMNEXAFS were externally-mixed; only the supermicron carboxylic acid-containing polysaccharides type was observed to be internally mixed with sea-salt. To summarise the available studies, marine POA seems to be both internally and externally mixed with sea-salt with smaller aerosols $(<200 \mathrm{~nm}$ in diameter) more likely to be externally mixed and larger 
aerosols ( $>1000 \mathrm{~nm}$ in diameter) more likely to be internally mixed.

\section{Global marine POA emissions}

Some of the first systematic laboratory experiments designed to study organic compounds in sea-spray production by bubble bursting were carried out in Blanchard (1963). Using bubbles produced by fine glass tips of capillary tubing, this study showed that the presence of surface-active organic film in seawater can have pronounced effects on the production of film and jet drops. For example, Blanchard (1963) showed that the amount of organics carried away by the jet formed from a $1.3 \mathrm{~mm}$ bubble is barely detectable, while the fraction increases rapidly, reaching about $200 \%$ at a bubble diameter of $3 \mathrm{~mm}$. Although the Blanchard (1963) results provided compelling evidence for the importance of organics in SSA production, their application to the ambient conditions has proven challenging due to the inconsistent results from various bubble populations and film compositions. Because field measurements of chemically-resolved emission rates of SSA have not been performed to complement laboratory studies, a combination of bottom-up inorganic-organic sea-spray functions based on concentration measurements and top-down modelling studies based on the optimisation of predicted and observed concentrations have been used to estimate global marine organic aerosol emissions. Prior to 2008, the only estimate for global emissions of marine organic aerosols came from Duce (1978), who estimated a rate of $14 \mathrm{Tg} \mathrm{C} \mathrm{yr}^{-1}$ (20 $\mathrm{Tg} \mathrm{yr}^{-1}$ assuming an organic matter/organic carbon ratio of 1.4) based on a uniform organic carbon/sea-salt mass ratio of $14 \times 10^{-3}$ and sea-salt emissions of $1000 \mathrm{Tg} \mathrm{yr}^{-1}$ (Eriksson, 1959). O'Dowd et al. (2008) applied the linear relationship between $\mathrm{OM}_{\mathrm{SSA}}$ and $[\mathrm{Chl} a$ ] to model marine organic aerosol emission rates in the North Atlantic Ocean. O'Dowd et al. (2008) also included a change in the size dependence of the SSA production flux as a function of the season. Recent work has expanded upon the relationship between marine organic aerosol emissions and [Chl $a$ ], including revisions to the linear dependence of $\mathrm{OM}_{\mathrm{SSA}}$ (Langmann et al., 2008; Vignati et al., 2010; Long et al., 2011), size-dependence of the SSA production flux (Vignati et al., 2010), size-dependence of the OMSSA (Long et al., 2011; Gantt et al., 2011), number distribution of the SSA production flux (Fuentes et al., 2010) and wind speed dependence of OMSSA (Gantt et al., 2011). These different studies using $\mathrm{OM}_{\mathrm{SSA}}$ as an emission parameter have global marine POA emission rates that vary in magnitude $\left(2-100 \mathrm{Tg} \mathrm{yr}^{-1}\right)$ and spatiotemporal distribution (especially in areas with extremely high or low $[\mathrm{Chl} a]$ ). Albert et al. (2012) explored some of the uncertainties related to estimates of the global submicron marine POA emission rate, finding that the choice of sea-spray aerosol source function and $\mathrm{OM}_{\mathrm{SSA}}$ calculation in low [Chl $a$ ] regions were the major factors affecting the global estimates.
Recent model estimates of global marine organic aerosol emissions have produced conflicting results. Spracklen et al. (2008) used a comparison of observed seasonal concentrations of organic aerosol at several coastal sites, and based on the remotely sensed $[\mathrm{Chl} a]$ in surface waters predicted concentrations from the chemical transport model GEOSChem (http://acmg.seas.harvard.edu/geos/) to estimate total (primary + secondary) marine organic aerosol emissions of $11 \mathrm{Tg} \mathrm{yr}^{-1}$, of which $8 \mathrm{Tg} \mathrm{yr}^{-1}$ were predicted to be in the submicron mode. Roelofs (2008) found that the ECHAM5-HAM model-predicted and satellite-derived liquid cloud effective radius in the North Atlantic was most similar with submicron marine organic aerosol emissions of $\sim 70 \mathrm{Tg} \mathrm{yr}^{-1}$. Vignati et al. (2010), using global ChemistryTransport Model TM5 coupled to a microphysical aerosol dynamics model, estimated a submicron marine POA source of $8.2 \mathrm{Tg} \mathrm{yr}^{-1}$. Lapina et al. (2011) found that global submicron marine POA emissions of $\sim 13 \mathrm{Tg} \mathrm{yr}^{-1}$ based on Spracklen et al. (2008) and Langmann et al. (2008) improves the GEOS-Chem prediction of surface mass concentration in marine regions, but does not explain the underestimation of aerosol optical depth. Using the Two-Moment Aerosol Sectional (TOMAS) microphysics algorithm coupled to the GISS II-prime general circulation model, Westervelt et al. (2012) estimated the total marine POA source to be $24.8 \mathrm{Tg} \mathrm{gr}^{-1}$. The simulated emission rate of marine POA using the NCAR Community Atmosphere Model (CAM v3.5.07) was $40.6 \mathrm{Tg} \mathrm{yr}^{-1}$ (Long et al., 2011), while the 7-mode Modal Aerosol Module (MAM7) of CAM version 5.0 (CAM-MAM7) produced emission rates of 7.9-9.4 and $18.6-23.0 \mathrm{Tg} \mathrm{yr}^{-1}$ for sub- and supermicron modes, respectively (Meskhidze et al., 2011). In a modelling study using five different marine POA emission schemes, Gantt et al. (2012a) highlighted the high level of uncertainty of recent emissions schemes by showing their large differences in magnitude and seasonality, as well as the inability to predict surface concentrations from hourly to monthly time scales. A submicron marine POA emission rate of $6.3 \mathrm{Tg} \mathrm{yr}^{-1}$ based on an OMSSA value strongly dependent on both [Chl $a]$ and wind speed best predicted the magnitude and seasonality of observed surface concentrations (Gantt et al., 2012a). The suitability of $[\mathrm{Chl} a]$ as a proxy for marine POA emissions was recently put into doubt when the organic mass fraction from nascent SSA produced by an in situ particle generator (Sea Sweep) was positively correlated with seawater DMS and not $[\mathrm{Chl} a]$ during a cruise off the California coast (Bates et al., 2012). While there is growing consensus from modelling efforts that global submicron marine POA emissions are roughly $10 \mathrm{Tg} \mathrm{yr}^{-1}$, the complexity of the emission processes results in predictions with high spatiotemporal variability and highlights the need for more field measurements of size- and chemically-resolved marine organic aerosol concentrations. 


\section{Impact on climate}

With observations of the chemical and physical characteristics and development of size-resolved aerosol emission parameterisations linked to sea-spray number and/or mass fluxes, it is possible to estimate the climatic impact of marine organic aerosols. By using the derived number size distribution of different aerosol types (estimated by applying the Twomey inversion algorithm (Twomey, 1975) to aerosol mass concentrations) and measured condensation nuclei (CN) concentration, Novakov and Penner (1993) and Novakov et al. (1997) first hypothesised that organic aerosols with a marine source play an important role in determining CCN concentrations. O'Dowd et al. (2004) used the chemical composition of size-resolved mass concentrations and number size distribution measurements from Mace Head to estimate the potential impact of marine organic aerosols on cloud droplet number concentration (CDNC), finding that the CDNC increases $15-20 \%$ and $100 \%$ for internal and external mixtures of sea-salt and organic aerosols, respectively. During clean marine air masses at Mace Head, Ovadnevaite et al. (2011b) found that periods in which aerosols had high organic fractions also had high observed CCN concentrations and CDNC. Two recent studies in which marine organic aerosols were implemented into global climate models are consistent with these estimates. Roelofs (2008) reported ECHAM5-HAM model results in which marine organic aerosols with global emissions of $70 \mathrm{Tg} \mathrm{yr}^{-1}$ distributed between the Aitken and accumulation modes and externallymixed with sea-salt increased North Atlantic CDNC by a factor of 3-4 ( $\sim 35$ to $\left.120 \mathrm{~cm}^{-3}\right)$ and decreased cloud effective radii from $15-20 \mu \mathrm{m}$ to $10-14 \mu \mathrm{m}$ in diameter. These increases in CDNC and decreases in cloud effective radii brought the model closer to satellite-derived values for the North Atlantic (Roelofs, 2008). After implementation of marine organic aerosols in the CAM-MAM7, Meskhidze et al. (2011) and Gantt et al. (2012b) described how the SSA mixing state determines the climatic impact. Marine POA that was externally-mixed with sea-salt (added to the model as additional aerosol number and mass) had a much greater impact on CCN and CDNC than an internal mixture of marine POA (added to the model only added as mass) and seasalt. Specifically, emissions of externally-mixed marine POA led to a $1.3 \%$ increase in global CCN surface concentration and a $\sim 0.1 \mathrm{~W} \mathrm{~m}^{-2}(7 \%)$ reduction in model-predicted aerosol indirect forcing (Meskhidze et al., 2011; Gantt et al., 2012b). The model simulations with externally-mixed marine organic aerosol emissions showed regional increases of $\sim 20 \%$ in CCN surface concentrations over the Southern Ocean, Arctic and Antarctic, while areas in the tropical Pacific and Atlantic Ocean had little changes. In the simulations with internally mixed marine organic aerosol, the CCN surface concentration and aerosol indirect forcing were not substantially different than the simulation without the inclusion of marine organic aerosols (Meskhidze et al., 2011; Gantt et al., 2012b). The importance of the mixing state of marine organic aerosols and sea-salt within SSA was also observed by Westervelt et al (2012) using the GISS II-prime climate model. When Westervelt et al. (2012) replaced highly hygroscopic sea-salt with lower hygroscopicity organics in internally mixed SSA, surface CCN concentrations decreased by $5 \%$ in the Southern Ocean and $<0.5 \%$ globally. The reduction in $\mathrm{CCN}$ was reported even with inclusion of surface tension depression effects of marine organic compounds (Moore et al., 2008; Westervelt et al., 2012). However, a sensitivity simulation in which marine organic aerosols were implemented as additional number emissions experienced increases in surface CCN concentration approaching 50\% in the Southern Ocean and $4 \%$ globally (Westervelt et al., 2012).

Despite several studies showing increases in $\mathrm{CCN}$ due to marine organic aerosols, hygroscopicity and $\mathrm{CCN}$ activity measurements of laboratory bubble bursting experiments (Fuentes et al., 2010; Moore et al., 2011; King et al., 2012) suggest a different climatic impact: the higher hydrophobicity and lower CCN activity of organic matter in sea-spray aerosol results in small changes in $\mathrm{CCN}$ concentration and resulting cloud properties associated with marine organic aerosols. However, extrapolation of the laboratory measurements of nascent sea-spray aerosol production to the cloud and climate scales should be done with caution, as marine organic aerosols could be of considerable importance to marine $\mathrm{CCN}$ concentrations even if they are emitted at a size below the critical diameter for aerosol activation. Field studies have shown that such organic aerosols could serve as growth nuclei for $\mathrm{CCN}$ through condensational growth by deposition of sulfate derived from DMS oxidation (Leck and Bigg, 2005). Modelling studies have shown that the CCN and cloud droplet number impact of marine organic aerosols is much more sensitive to physical properties (e.g., mixing state and number emission rate) than chemical (e.g., hygroscopicity) (Gantt et al., 2012b). Despite this indication of the climatic importance of the physical properties of marine organic aerosols, many of these modelling studies prescribe their characteristics (size distribution, photochemical aging, hygroscopicity, etc.) to be the same as that of terrestrial POA which may not be representative. As the understanding of mixing state and CCN impact of marine organic aerosol emissions is evolving, future climate studies would be well served to assume both external and internal mixtures of organics and sea-salt in SSA, and incorporate detailed aerosol microphysics in order to place upper and lower bounds on the climatic impact of marine POA.

An emerging issue related to the climate impact of marine POA is their ability to serve as ice nuclei (IN). Bigg (1973) provided early measurements of IN over marine regions, with the highest concentrations centered over a HBA Southern Ocean region with strong winds. The research into sources of atmospheric nuclei in marine environments showed that some component of the surface plankton biomass may 
contain ice nuclei that are active at $-10^{\circ} \mathrm{C}$ in concentrations of up to $10^{8}$ ice nuclei per gram of plankton, and some that are active at temperatures as warm as $-3^{\circ} \mathrm{C}$ (Schnell and Vali, 1975). Recent experimental measurements identified IN activity of the cosmopolitan marine diatom species Thalassiosira pseudonana (Knopf et al., 2011; Alpert et al., 2011a) and marine microalga Nannochloris atomus (Alpert et al., 2011b) for the conditions conducive to cirrus-cloud formation. In aqueous sodium chloride solution the presence of diatoms increased the freezing temperatures by up to $30 \mathrm{~K}$ above predicted homogeneous freezing temperatures (Knopf et al., 2011; Alpert et al., 2011a). However, it should be noted that all plankton cultures do not exhibit ice nucleation activity in laboratory tests, and some samples from highlatitude waters have also been observed to inhibit, rather than promote, ice formation (Junge and Swanson, 2008). Extensive review of IN in marine air can be found in Burrows et al. (2012). The IN-related climate impact of marine POA is highly uncertain with the sign and magnitude not yet known. Concurrent measurements of $\mathrm{CCN}$ and IN activity of marine POA in laboratory and field studies, along with the inclusion of marine POA in ice nucleation processes within climate models, will help address this uncertainty.

\section{Discussion and future directions}

Improvements in instrumentation and computer modelling have enabled a more comprehensive and quantitative view of chemistry, physics, and potential climatic impact of marine primary organic aerosol (POA). Although certain locations near biologically productive waters can have episodic high concentrations $\left(>3.0 \mu \mathrm{g} \mathrm{m}^{-3}\right)$, the average mass concentration of marine POA is typically around $0.4 \mu \mathrm{g} \mathrm{m}^{-3}$. Despite having such low mass concentrations, the number concentration of marine-source organic aerosols has been suggested to be comparable to (if not greater than) sea-salt aerosols in the climate-relevant size range between $\sim 50$ and $150 \mathrm{~nm}$ in diameter. The organic mass fraction of sea-spray aerosol (SSA) has been consistently shown to be inversely related to the aerosol size, with the magnitude of organic mass fraction for a given aerosol size dependent on seawater chemical and biological composition, as well as meteorological fields such as wind speed. Despite the development of an adsorption model describing how the aerosol size affects the relative contributions of organic matter and sea-salt, it is still an open question whether this is the case, or if they are simply co-varying quantities. One reason for such uncertainty is the difficulty in scaling up bubble tank experiments to ambient conditions, as processes like bubble clustering, surface foam creation, and the presence of wind affect marine POA production, but are not always simulated realistically. There is general agreement that the chemical composition of SSA organic fraction is similar to that of seawater, with polysaccharides, phytoplankton fragments/secretions, and proteinaceous aerosols all contributing to the total mass. Chemical indicators that can be used to determine a marine POA include hygroscopic growth factors, volatility, and spectroscopic, isotopic and microscopic analyses of signatures unique to organics in seawater. Global emission estimates of the climate-relevant submicron-sized marine POA have averaged $\sim 10 \mathrm{Tg} \mathrm{yr}^{-1}$, but vary by nearly an order of magnitude in different studies.

By taking a historical perspective on marine POA research, certain trends seem to have emerged since the initial research began in the 1960-1980's. Despite some contradictory results, recent studies have described the existence of both external and internal mixtures of marine organic aerosol and sea-salt, changes in the aerosol number size distribution due to marine organics, and the importance of marine POA (with diameters between 50 and $150 \mathrm{~nm}$ ) for the MBL cloud condensation nuclei (CCN) budget. The increasing complexity of climate and air quality models and novel parameterisations for SSA source functions has enabled researchers to implement marine POA in both regional and global climate models. The few modelling studies that have been performed show regionally substantial changes in $\mathrm{CCN}$ concentration, cloud droplet number concentration, liquid cloud microphysical properties and shortwave cloud forcing resulting from marine organic aerosols. The change in aerosol indirect forcing due to marine POA has been estimated to be $\sim 0.1 \mathrm{~W} \mathrm{~m}^{-2}(7 \%)$. Future development of marine organic aerosol emission parameterisations will likely proceed in two distinct directions: (1) a size-dependent marine organic aerosol source function (likely a function of $[\mathrm{Chl} a], 10 \mathrm{~m}$ wind speed, dissolved organic matter, phytoplankton senescence and/or bacterial abundance) that calculates the number and mass emission rates independent of sea-salt or (2) an updated sea-spray source function whose whitecap fraction and number size distribution are a function of several oceanic biological/chemical factors ([Chl $a]$, phytoplankton senescence, bacterial abundance, dissolved organic matter) in addition to the existing power relationship with $10 \mathrm{~m}$ wind speed. Modelling efforts attempting to further quantify the climatic impact of marine organic aerosols need to be explicit in their treatment of the size distribution, mixing state, hygroscopicity, atmospheric transformations and removal of marine organic aerosols.

In order to expand upon the physical and chemical understanding of marine POA, more synergistic measurements are needed. With any measurement of marine aerosol chemistry and size distribution, supplementary measurements of meteorological and oceanic physical/chemical/biological variables should also be performed. These supplementary measurements include wind speed, relative humidity, precipitation rates, whitecap fraction, bubble properties, chlorophyll- $a$, dissolved organic matter, particulate organic concentrations and phytoplankton speciation among others. Some combination of spectroscopic, isotopic, and microscopic analyses of organic aerosols needs to be performed to differentiate marine organic aerosols from those 
with anthropogenic/terrestrial sources. High temporal resolution measurements of the volatility, hygroscopicity, or AMSderived chemistry of SSA would be of particular value because they can give the chemically-resolved emission (and deposition) rates of SSA when combined with eddy covariance techniques. Optimally, these measurements would be size-resolved in the climate-relevant $50-150 \mathrm{~nm}$ diameter size range. Single particle analysis of marine organic aerosol chemical and physical characteristics is needed alongside these bulk aerosol measurements to determine the frequency of different mixing states, unique chemical signatures and composition. Such measurements need to be taken in many ocean regions with a diverse set of meteorological, oceanic and biological parameters. Areas such as the tropical Pacific Ocean and Southern Ocean would be good candidates for future field campaigns. As the seasonality of marine POA concentrations is distinct from that of sea-salt aerosol, long-term measurements at additional sites would be helpful in formulating improved emission parameterizations and evaluating existing ones. For all field campaigns, concentration measurements (with a very low detection limit) of anthropogenicand continental-derived constituents such as black carbon and radon should be performed in order to minimise the non-marine organic aerosol influence. Laboratory measurements of bubble bursting experiments need to both simulate real world conditions and systematically test the individual processes (i.e., surfactant composition, bubble size/spectra, wind speed, phytoplankton abundance/speciation, dissolved organic carbon, etc.) that may affect the chemical and physical characteristics of marine POA.

\section{Supplementary material related to this article is available online at: http://www.atmos-chem-phys.net/13/ 3979/2013/acp-13-3979-2013-supplement.pdf.}

Acknowledgements. This research was supported by the Office of Science (BER), US Department of Energy Grant No. DE-FG0208ER64508. BG was supported by the NASA Earth and Space Science Fellowship (NESSF) Program. We also thank Jurgita Ovadnevaite, Darius Ceburnis, Colin O'Dowd, and Jean Sciare for providing the Mace Head and Amsterdam Island data and the two anonymous reviewers for their comments.

Edited by: M. Kanakidou

\section{References}

Albert, M. F. M. A., Schaap, M., Manders, A. M. M., Scannell, C., O'Dowd, C. D., and de Leeuw, G., Uncertainties in the determination of global sub-micron marine organic matter emissions, Atmos. Environ., doi:10.1016/j.atmosenv.2012.04.009, 2012.

Alpert, P. A., Aller, J. Y., and Knopf, D. A.: Ice nucleation from aqueous $\mathrm{NaCl}$ droplets with and without marine diatoms, At- mos. Chem. Phys., 11, 5539-5555, doi:10.5194/acp-11-55392011, 2011a.

Alpert, P. A., Aller, J. Y., and Knopf, D. A.: Initiation of the ice phase by marine biogenic surfaces in supersaturated gas and supercooled aqueous phases, Phys. Chem. Chem. Phys., 13, 19882-19894, doi:10.1039/c1cp21844a, 2011b.

Aluwihare, L. I., Repeta, D. J., and Chen, R. F.: A major biopolymeric component to dissolved organic carbon in surface sea water, Nature, 387, 6629, 166-169, 1997.

Andreae, M. O.: Aerosols before pollution, Science, 315, 50-51, doi:10.1126/science.1136529, 2007.

Andreae, M. O. and Rosenfeld, D.: Aerosol-cloud-precipitation interactions, Part 1, The nature and sources of cloud-active aerosols, Earth Sci. Rev., 89, 13-41, 2008.

Barger, W. R. and Garrett, W. D.: Surface active organic material in the marine atmosphere, J. Geophys. Res., 75, 4561-4566, 1970.

Barger, W. R. and Garrett, W. D.: Surface-active organic material in air over the mediterranean and over the eastern equatorial pacific, J. Geophys. Res., 81, 3151-3157, 1976.

Barker, D. R. and Zeitlin, H.: Metal-ion concentrations in seasurface microlayer and size separated atmospheric aerosol samples in Hawaii, J. Geophys. Res., 77, 5076-5086, 1972.

Bates, T. S., Calhoun, J. A., and Quinn, P. K.: Variations in the concentration ratio of methane-sulfonate to sulfate in marine aerosol particles over the South Pacific Ocean, J. Geophys. Res., 97, 9859-9865, 1992.

Bates, T. S., Quinn, P. K., Coffman, D. J., Johnson, J. E., and Middlebrook, A. M.: Dominance of organic aerosols in the marine boundary layer over the Gulf of Maine during NEAQS 2002 and their role in aerosol light scattering, J. Geophys. Res., 110, D18202, doi:10.1029/2005JD005797, 2005.

Bates, T. S., Quinn, P. K., Frossard, A. A., Russell, L. M., Hakala J., Petäjä, T., Kulmala, M., Covert, D. S., Cappa, C. D., Li, S.-M., Hayden, K. L., Nuaaman, I., McLaren, R., Massoli, P., Canagaratna, M. R, Onasch, T. B., Sueper, D., Worsnop, D. R., and Keene, W. C.: Measurements of ocean derived aerosol off the coast of California, J. Geophys. Res., 117, D00V15, doi:10.1029/2012JD017588, 2012.

Bauer, J. E.: Carbon isotopic composition of DOM, in Biogeochemistry of marine dissolved organic matter, edited by: Hansell, D. A. and Carlson, C. A., Academic Press, San Diego, CA, USA, 405-453, 2002.

Benner, R.: Chemical composition and reactivity, in Biogeochemistry of marine dissolved organic matter, edited D. A. Hansell and C. A. Carlson, Academic Press, San Diego, CA, USA, 5990, 2002.

Benner, R., Pakulaki, J. D., McCarthy, M., Hegdes, J. I., and Hatcher, P. G.: Bulk chemical characteristics of dissolved organic matter in the ocean, Science, 255, 1561-1564, 1992.

Bigg, E. K.: Ice nucleus concentrations in remote areas, J. Atmos. Sci., 30, 1153-1157, 1973.

Bigg, E. K. and Leck, C.: Cloud-active particles over the central Arctic Ocean, J. Geophys. Res., 106, 32155-32166, doi:10.1029/1999JD901152, 2001.

Bigg, E. K. and Leck, C.: The composition of fragments of bubbles bursting at the ocean surface, J. Geophys. Res., 113, D11209, doi:10.1029/2007JD009078, 2008.

Blanchard, D. C.: The electrification of the atmosphere by particles from bubbles in the sea, Prog. Oceanogr., 1, 71-202, 1963. 
Blanchard, D. C.: Sea-to-air transport of surface active material, Science, 146, 396-397, doi:10.1126/science.146.3642.396, 1964.

Blanchard, D. C.: Surface active organic material on airborne salt particles, Proc. Int. Conf.-Cloud Physics, 25-29, Toronto, Canada, 1968.

Blanchard, D. C. and Woodcock A. H.: Bubble formation and modification in the sea and its meteorological significance, Tellus, 9, 145-158, 1957.

Bonsang, B., Polle, C., and Lambert, G.: Evidence for marine production of isoprene, Geophys. Res. Lett., 19, 1129-1132, 1992.

Boutton, T. W.: Stable carbon isotope ratios of natural materials: II. Atmospheric, terrestrial, marine, and freshwater environments, in: Carbon Isotope Techniques, Academic Press, New York, USA, 173-184, 1991.

Burrows, S. M., Hoose, C., Pöschl, U., and Lawrence, M. G.: Ice nuclei in marine air: biogenic particles or dust?, Atmos. Chem. Phys., 13, 245-267, doi:10.5194/acp-13-245-2013, 2013.

Cachier, H.: Isotopic characterization of carbonaceous aerosols, Aerosol Sci. Technol., 10, 379-385, 1989.

Carslaw, K. S., Boucher, O., Spracklen, D. V., Mann, G. W., Rae, J. G. L., Woodward, S., and Kulmala, M.: A review of natural aerosol interactions and feedbacks within the Earth system, Atmos. Chem. Phys., 10, 1701-1737, doi:10.5194/acp-10-17012010, 2010.

Cavalli, F., Facchini, M. C., Decesari, S., Mircea, M., Emblicia, L., Fuzzi, S., Ceburnis, D., Yoon, Y. J., O'Dowd, C. D., Putaud, J.P., and Dell'Acqua, A.: Advances in characterization of size resolved organic matter in marine aerosol over the North Atlantic, J. Geophys. Res., 109, D24215, doi:10.1029/2004JD005137, 2004.

Ceburnis, D., Garbaras, A., Szidat, S., Rinaldi, M., Fahrni, S., Perron, N., Wacker, L., Leinert, S., Remeikis, V., Facchini, M. C., Prevot, A. S. H., Jennings, S. G., Ramonet, M., and O'Dowd, C. D.: Quantification of the carbonaceous matter origin in submicron marine aerosol by $13 \mathrm{C}$ and $14 \mathrm{C}$ isotope analysis, Atmos. Chem. Phys., 11, 8593-8606, doi:10.5194/acp-11-85932011, 2011.

Charlson, R. J., Lovelock, J. E. Andreae, M. O., and Warren, S. G.: Oceanic phytoplankton, atmospheric sulphur, cloud albedo and climate, Nature, 326, 6114, 655-661, 1987.

Chesselet, R., Fontugne, M., Buatmenard, P., Ezat, U., and Lambert, C. E.: The origin of particulate organic carbon in the marine atmosphere as indicated by its stable carbon isotopic composition, Geophys. Res. Lett., 8, 345-348, 1981.

Clarke, A.: Aerosol light absorption by soot in remote environments, Aerosol Sci. Technol., 10, 161-171, 1989.

Craig, H.: The geochemistry of the stable carbon isotopes, Geochim. Cosmochim. Ac., 3, 53-92, 1953.

Decesari, S., Finessi, E., Rinaldi, M., Paglione, M., Fuzzi, S., Stephanou, E., Tziaras, T., Spyros, A., Ceburnis, D., O’Dowd, C. D., Dall'Osto, M., Harrison, R., Allan, J., Coe, H., and Facchini, M. C.: Primary and secondary marine organic aerosols over the North Atlantic Ocean during the MAP experiment, J. Geophys. Res., 116, D22210, doi:10.1029/2011JD016204, 2011.

de Leeuw, G., Moerman, M., Zappa, C. J., McGillis, W. R., Norris, S. J., and Smith, M. H.: Eddy Correlation Measurements of Sea Spray Aerosol Fluxes, in: Transport at the Air Sea Interface, edited by: Garbe, C. S., Handler, R. A., and Jähne, B., Springer-
Verlag Berlin, Heidelberg, Germany, 2007.

de Leeuw, G., Andreas, E. L., Anguelova, M. D., Fairall, C. W., Lewis, E. R., O'Dowd, C., Schulz, M., and Schwartz, S. E.: Production flux of sea spray aerosol, Rev. Geophys., 49, RG2001, doi:10.1029/2010RG000349, 2011.

Duce, R. A.: Speculations on the budget of particulate and vapor phase nonmethane organic carbon in the global troposphere, Pure Appl. Geophys., 116, 244-273, 1978.

Ellison, G. B., Tuck, A. F., and Vaida, V.: Atmospheric processing of organic aerosols, J. Geophys. Res., 104, 11633-11641, 1999.

Eriksson, E.: The yearly circulation of chloride and sulfur in nature: meteorological, geochemical, and pedological implications, Part 1, Tellus, 11, 375-403, 1959.

Facchini, M. C., Decesari, S., Rinaldi, M., Carbone, C., Finessi, E., Mircea, M., Fuzzi, S., Moretti, F., Tagliavini, E., Ceburnis, D., and O'Dowd, C. D.: Important source of marine secondary organic aerosol from biogenic amines, Environ. Sci. Technol., 42, 9116-9121, 2008a.

Facchini, M. C., Rinaldi, M., Decesari, S., Carbone, C., Finessi, E., Mircea, M., Fuzzi, S., Ceburnis, D., Flanagan, R., Nilsson, D., de Leeuw, G., Martino, M., Woeltjen, J., and O'Dowd, C. D.: Primary sub-micron marine aerosol dominated by insoluble organic colloids and aggregates, Geophys. Res. Lett., 35, L17814, doi:10.1029/2008GL034210, 2008b.

Fang, J., Kawamura, K., Ishimura, Y., and Matsumoto, K.: Carbon isotopic composition of fatty acids in the marine aerosols from the western North Pacific: Implication for the source and atmospheric transport, Environ. Sci. Technol., 36, 2598-2604, doi:10.1021/es015863m, 2002.

Fry, B., Hopkinson C. S. Jr., Nolin, A., and Wainright, S. C.: ${ }^{13} \mathrm{C} /{ }^{12} \mathrm{C}$ composition of marine dissolved organic carbon, Chem. Geol., 152, 113-118, 1998.

Fuentes, E., Coe, H., Green, D., de Leeuw, G., and McFiggans, G.: On the impacts of phytoplankton-derived organic matter on the properties of the primary marine aerosol - Part 1: Source fluxes, Atmos. Chem. Phys., 10, 9295-9317, doi:10.5194/acp-10-92952010, 2010.

Fuentes, E., Coe, H., Green, D., and McFiggans, G.: On the impacts of phytoplankton-derived organic matter on the properties of the primary marine aerosol - Part 2: Composition, hygroscopicity and cloud condensation activity, Atmos. Chem. Phys., 11, 25852602, doi:10.5194/acp-11-2585-2011, 2011.

Gantt, B., Meskhidze, N., and Kamykowski, D.: A new physicallybased quantification of marine isoprene and primary organic aerosol emissions, Atmos. Chem. Phys., 9, 4915-4927, doi:10.5194/acp-9-4915-2009, 2009.

Gantt, B., Meskhidze, N., Facchini, M. C., Rinaldi, M., Ceburnis, D., and O'Dowd, C. D.: Wind speed dependent size-resolved parameterization for the organic mass fraction of sea spray aerosol, Atmos. Chem. Phys., 11, 8777-8790, doi:10.5194/acp-11-87772011, 2011.

Gantt, B., Johnson, M. S., Meskhidze, N., Sciare, J., Ovadnevaite, J., Ceburnis, D., and O'Dowd, C. D.: Model evaluation of marine primary organic aerosol emission schemes, Atmos. Chem. Phys., 12, 8553-8566, doi:10.5194/acp-12-8553-2012, 2012 a.

Gantt, B., Xu, J., Meskhidze, N., Zhang, Y., Nenes, A., Ghan, S. J., Liu, X., Easter, R., and Zaveri, R.: Global distribution and climate forcing of marine organic aerosol - Part 2: Effects on cloud properties and radiative forcing, Atmos. Chem. Phys., 12, 
6555-6563, doi:10.5194/acp-12-6555-2012, 2012b.

Garrett, W. D.: Influence of monomolecular surface films on production of condensation nuclei from bubbled sea water, J. Geophys. Res., 73, 5145-5150, doi:10.1029/JB073i016p05145, 1968.

Gaston, C. J., Furutani, H., Guazzotti, S. A., Coffee, K. R., Bates, T. S., Quinn, P. K., Aluwihare, L. I., Mitchell, B. G., and Prather, K. A.: Unique ocean-derived particles serve as a proxy for changes in ocean chemistry, J. Geophys. Res., 116, D18310, doi:10.1029/2010JD015289, 2011.

Gershey, R. M.: Characterization of seawater organic matter carried by bubble-generated aerosols, Limnol. Oceanogr., 28, 309-319, 1983.

Gilardoni, S., Russell, L. M., Sorooshian, A., Flagan, R. C., Seinfeld, J. H., Bates, T. S., Quinn, P. K., Allan, J. D., Williams, B., Goldstein, A. H., Onasch, T. B., and Worsnop, D. R.: Regional variation of organic functional groups in aerosol particles on four US east coast platforms during the International Consortium for Atmospheric Research on Transport and Transformation 2004 campaign, J. Geophys. Res.-Atmos., 112, D10S27, doi:10.1029/2006jd007737, 2007.

Hansell, D., Carlson, C. A., Repeta, D. J., and Schlitzer, R.: Dissolved organic matter in the ocean: A controversy stimulates new insights, Oceanography, 22, 202-211, 2009.

Hawkins, L. N. and Russell, L. M.: Polysaccharides, proteins, and phytoplankton fragments: four chemically distinct types of marine primary organic aerosol classified by single particle spectromicroscopy, Adv. Meteorol., 612132, doi:10.1155/2010/612132, 2010.

Hawkins, L. N., Russell, L. M., Covert, D. S., Quinn, P. K., and Bates, T. S.: Carboxylic acids, sulfates, and organosulfates in processed continental organic aerosol over the southeast Pacific Ocean during VOCALS-REx 2008, J. Geophys. Res., 115, D13201, doi:10.1029/2009JD013276, 2010.

Hoffman, E. J. and Duce, R.: The organic carbon content of marine aerosols collected on Bermuda, J. Geophys. Res., 79, 44744477, 1974.

Hoffman, E. J. and Duce, R.: Factors influencing the organic carbon content of marine aerosols: A laboratory study, J. Geophys. Res., 81, 3667-3670, 1976.

Hoffman, E. J. and Duce, R.: Organic carbon in marine atmospheric particulate matter: Concentration and particle size distribution, Geophys. Res. Lett., 4, 449-452, doi:10.1029/GL004i010p00449, 1977.

Hoose, C., Kristjánsson, J. E., Iversen, T., Kirkevåg, A., Seland, Ø., and Gettelman, A.: Constraining cloud droplet number concentration in GCMs suppresses the aerosol indirect effect, Geophys. Res. Lett., 36, L12807, doi:10.1029/2009GL038568, 2009.

Hultin, K. A. H., Nilsson, E. D., Krejci, R., Mårtensson, E. M., Ehn, M., Hagström, A., and de Leeuw, G.: In situ laboratory sea spray production during the Marine Aerosol Production 2006 cruise on the northeastern Atlantic Ocean, J. Geophys. Res., 115, D06201, doi:10.1029/2009JD012522, 2010.

Junge, K. and Swanson, B. D.: High-resolution ice nucleation spectra of sea-ice bacteria: implications for cloud formation and life in frozen environments, Biogeosciences, 5, 865-873, doi:10.5194/bg-5-865-2008, 2008.

Kawamura, K. and Gagosian, R. B.: Implications of $\omega$ oxocarboxylic acids in the remote marine atmosphere for pho- tooxidation of unsaturated fatty acids, Nature, 325, 330-332, 1987.

Kawamura, K., Ono, K., Tachibana, E., Charriére, B., and Sempéré, R.: Distributions of low molecular weight dicarboxylic acids, ketoacids and $\alpha$-dicarbonyls in the marine aerosols collected over the Arctic Ocean during late summer, Biogeosciences, 9, 47254737, doi:10.5194/bg-9-4725-2012, 2012.

Keene, W. C., Maring, H., Maben, J. R., Kieber, D. J., Pszenny, A. A. P., Dahl, E. E., Izaguirre, M. A., Davis, A. J., Long, M. S., Zhou, X. L., Smoydzin, L., and Sander, R.: Chemical and physical characteristics of nascent aerosols produced by bursting bubbles at a model air-sea interface, J. Geophys. Res., 112, D21202, doi:10.1029/2007JD008464, 2007.

Kieber, D. J. and Mopper, K.: Photochemical formation of glyoxylic and pyruvic acids in seawater, Mar. Chem., 21, 135-149, 1987.

Kieber, R. J., Zhou, X., and Mopper, K.: Formation of carbonyl compounds from UV-induced photodegradation of humic substances in natural waters: Fate of riverine carbon in the sea, Limnol. Oceanogr., 35, 1503-1515, 1990

King, S. M., Butcher, A. C., Rosenoern, T., Coz, E., Lieke, K. I., de Leeuw, G., Nilsson, E. D., and Bilde, M.: Investigating primary marine aerosol properties: CCN activity of sea salt and mixed inorganic-organic particles, Environ. Sci. Technol., 46, 1040510412, doi:10.1021/es300574u, 2012.

Klippel, W. and Warneck, P.: The formaldehyde content of the atmospheric aerosol, Atmospheric Environ., 14, 809-818, 1980.

Knopf, D. A., Alpert, P. A., Wang, B., and Aller, J. Y.: Stimulation of ice nucleation by marine diatoms, Nat. Geosci., 4, 88-90, doi:10.1038/ngeo1037, 2011.

Langmann, B., Scannell, C., and O'Dowd, C.: New directions: organic matter contribution to marine aerosols and cloud condensation nuclei, Atmos. Environ., 42, 7821-7822, 2008.

Lapina, K., Heald, C. L., Spracklen, D. V., Arnold, S. R., Allan, J. D., Coe, H., McFiggans, G., Zorn, S. R., Drewnick, F., Bates, T. S., Hawkins, L. N., Russell, L. M., Smirnov, A., O’Dowd, C. D., and Hind, A. J.: Investigating organic aerosol loading in the remote marine environment, Atmos. Chem. Phys., 11, 8847-8860, doi:10.5194/acp-11-8847-2011, 2011.

Leck, C. and Bigg, E. K.: Aerosol production over remote marine areas - a new route, Geophys. Res. Lett., 26, 3577-3580, 1999.

Leck, C. and Bigg, E. K.: Source and evolution of the marine aerosol - A new perspective, Geophys. Res. Lett., 32, L19803, doi:10.1029/2005GL023651, 2005.

Leck, C. and Bigg, E. K.: Comparison of sources and nature of the tropical aerosol with the summer high arctic aerosol, Tellus B, 118-126, doi:10.1111/j.1600-0889.2007.00315.x, 2008.

Leck, C. and Bigg, E. K.: New particle formation of marine biological origin, Aerosol Sci. Technol., 44, 570-577, 2010.

Leck, C., Norman, M., Bigg, E. K., and Hillamo, R.: Chemical composition and sources of the high Arctic aerosol relevant for fog and cloud formation, J. Geophys. Res., 107, 4135, doi:10.1029/2001JD001463, 2002.

Lewis, R. and Schwartz, S. E.: Sea Salt Aerosol Production: Mechanisms, Methods, Measurements, and Models - A Critical Review, Geophysical monograph 152, 413 pp., American Geophysical Union, Washington, DC, 2004.

Long, M. S., Keene, W. C., Kieber, D. J., Erickson, D. J., and Maring, H.: A sea-state based source function for size- and composition-resolved marine aerosol production, Atmos. Chem. 
Phys., 11, 1203-1216, doi:10.5194/acp-11-1203-2011, 2011.

Luo, G. and Yu, F.: A numerical evaluation of global oceanic emissions of $\alpha$-pinene and isoprene, Atmos. Chem. Phys., 10, 20072015, doi:10.5194/acp-10-2007-2010, 2010.

Maria, S. F., Russell, L. M., Gilles, M. K., and Myneni, S. C. B.: Organic aerosol growth mechanisms and their climate-forcing implications, Science, 306, 1921-1924, doi:10.1126/science.1103491, 2004.

Marty, J. C., Saliot, A., Buat-Ménard, P., Chesselet, R., and Hunter, K. A.: Relationship between the lipid compositions of marine aerosols, the sea surface microlayer, and subsurface water, J. Geophys. Res., 84, 5707-5716, doi:10.1029/JC084iC09p05707, 1979.

Menzel, D. W. and R. F. Vaccaro, R. F.: The measurement of dissolved organic and particulate carbon in seawater, Limnol. Oceanogr., 9, 138-142, doi:10.4319/lo.1964.9.1.0138, 1964.

Meskhidze, N. and Nenes, A.: Phytoplankton and cloudiness in the Southern Ocean, Science, 314, 1419-1423, doi:10.1126/science.1131779, 2006.

Meskhidze, N., Xu, J., Gantt, B., Zhang, Y., Nenes, A., Ghan, S. J., Liu, X., Easter, R., and Zaveri, R.: Global distribution and climate forcing of marine organic aerosol: 1. Model improvements and evaluation, Atmos. Chem. Phys., 11, 11689-11705, doi:10.5194/acp-11-11689-2011, 2011.

Michener, R. H., and Schell, D. M.: Stable isotope ratios as tracers in marine aquatic food webs, edited by: Lajtha, K. and Michener, R., in: Stable isotopes in ecology and environmental science, Blackwell Scientific, Oxford, UK, 138-157, 1994.

Middlebrook, A. M., Murphy, D. M., and Thomson, D. S.: Observations of organic material in individual marine particles at Cape Grim during the First Aerosol Characterization Experiment (ACE1), J. Geophys. Res., 103, 16475-16483, doi:10.1029/97JD03719, 1998.

Millero, F. J.: Chemical Oceanography, 3rd ed, Taylor \& Francis Group CRC Press, 496 pp., 2006.

Miyazaki, Y., Kawamura, K., and Sawano, M.: Size distributions and chemical characterization of water-soluble organic aerosols over the Western North Pacific in summer, J. Geophys. Res., 115, D23210, doi:10.1029/2010JD014439, 2010.

Mochida, M., Kitamori, Y., Kawamura, K., Nojiri, Y., and Suzuki, K.: Fatty acids in the marine atmosphere: Factors governing their concentrations and evaluation of organic films on sea-salt particles, J. Geophys. Res., 107, 4325, doi:10.1029/2001JD001278, 2002.

Modini, R. L., Harris, B., and Ristovski, Z. D.: The organic fraction of bubble-generated, accumulation mode Sea Spray Aerosol (SSA), Atmos. Chem. Phys., 10, 2867-2877, doi:10.5194/acp10-2867-2010, 2010a.

Modini, R. L., Johnson, G. R., He, C., and Ristovski, Z. D.: Observation of the suppression of water uptake by marine particles, Atmos. Res., 98, 219-228, 2010 b.

Modini, R. L., Russell, L. M., Deane, G. B., and Stokes, M. D.: Effect of soluble surfactant on bubble persistence and bubbleproduced aerosol particles, J. Geophys. Res. Atmos., 118, 13881400, doi:10.1002/jgrd.50186, 2013.

Moore, R. H., Ingall, E. D., Sorooshian, A., and Nenes, A.: Molar mass, surface tension, and droplet growth kinetics of marine organics from measurements of CCN activity, Geophys. Res. Lett., 35, L07801, doi:10.1029/2008GL033350, 2008.
Moore, M. J. K., Furatani, H., Roberts, G. C., Moffet, R. C., Giles, M. K., Palenik, B., and Prather, K. A.: Effect of organic compounds on cloud condensation nuclei $(\mathrm{CCN})$ activity of sea spray aerosol produced by bubble bursting, Atmos. Environ., 45, 74627469, doi:10.1016/j.atmosenv.2011.04.034, 2011.

Mopper, K., Zhou, X., Kieber, R. J., Kieber, D. J., Sikorski, R. J., and Jones, R. D.: Photochemical degradation of dissolved organic-carbon and its impact on the oceanic carbon-cycle, Nature, 353, 60-62, doi:10.1038/353060a0, 1991.

Murphy, D. M., Thomson, D. S., and Mahoney, M. J.: In situ measurements of organics, meteoritic material, mercury and other elements in aerosols at 5 to 19 kilometers, Science, 282, 16641668, 1998.

Myriokefalitakis, S., Vignati, E., Tsigaridis, K., Papadimas, C., Sciare J., Mihalopoulos, N., Facchini, M.C., Rinaldi, M., Dentener, F. J., Ceburnis, D., Hatzianastasiou, N., O’Dowd, C. D., van Weele, M., and Kanakidou, M.: Global modelling of the oceanic source of organic aerosols, Adv. Meteorol., 2010, 939171, 16 pp., doi:10.1155/2010/939171, 2010.

Narukawa, M., Kawamura, K., Li, S. M., and Bottenheim, J. W.: Stable carbon isotopic ratios and ionic composition of the high-Arctic aerosols: An increase in delta C-13 values from winter to spring, J. Geophys. Res., 113, D02312, doi:10.1029/2007jd008755, 2008.

Nilsson, E. D., Rannik, U., Swietlicki, E., Leck, C., Aalto, P. P., Zhou, J., and Norman, M.: Turbulent aerosol fluxes over the Arctic Ocean 2.Wind-driven sources from the sea, J. Geophys. Res., 106, 32139-32154, 2001.

Novakov, T. and Penner, J. E.: Large contribution of organic aerosols to cloud condensation nuclei concentrations, Nature, 365, 823-826, 1993.

Novakov, T., Corrigan, C. E., Penner, J. E., Chuang, C. C., Rosario, O., and Mayel Bracero, O. L.: Organic aerosols in the Caribbean trade winds: A natural source?, J. Geophys. Res., 102, 21307 21313, doi:10.1029/97JD01487, 1997.

O’Dowd, C. D. and de Leeuw, G.: Marine aerosol production: a review of the current knowledge, Phil. Trans. R. Soc. A, 365, 1753-1774, doi:10.1098/rsta.2007.2043, 2007.

O'Dowd, C. D., Lowe, J. A, and Smith, M. H.: Marine aerosol, sea-salt, and the marine sulphur cycle: A short review, Atmos. Environ., 31, 73-80, 1997.

O’Dowd, C. D., Facchini, M. C., Cavalli, F., Ceburnis, D., Mircea, M., Decesari, S., Fuzzi, S., Yoon, Y. J., and Putaud, J. P.: Biogenically driven organic contribution to marine aerosol, Nature, 431, 676-680, doi:10.1038/nature02959, 2004.

O’Dowd, C. D., Langmann, B., Varghese, S., Scannell, C., Ceburnis, D., and Facchini, M. C.: A combined organic-inorganic sea-spray source function, Geophys. Res. Lett., 35, L01801, doi:10.1029/2007GL030331, 2008.

Oppo, C., Bellandi, S., DegliInnocenti, N., Stortini, A. M., Loglio, G., Schiavuta, E., and Cini, R.: Surfactant components of marine organic matter as agents for biogeochemical fractionation and pollutant transport via marine aerosols, Mar. Chem., 63, 235253, 1999.

Orellana, M. V., Matrai, P. A., Leck, C., Rauschenberg, C. D., Lee, A. M., and Coz, E.: Marine microgels as a source of cloud condensation nuclei in the high Arctic, P. Natl. Acad. Sci., 108, 13612-13617, doi:10.1073/pnas.1102457108, 2011. 
Ovadnevaite, J., O'Dowd, C., Dall'Osto, M., Ceburnis, D., Worsnop, D. R., and Berresheim, H.: Detecting high contributions of primary organic matter to marine aerosol: A case study, Geophys. Res. Lett., 38, L02807, doi:10.1029/2010GL046083, 2011a.

Ovadnevaite, J., Ceburnis, D., Martucci, G., Bialek, J., Monahan, C., Rinaldi, M., Facchini, M. C., Berresheim, H., Worsnop, D. R., and O'Dowd, C.: Primary marine organic aerosol: A dichotomy of low hygroscopicity and high CCN activity, Geophys. Res. Lett., 38, L21806, doi:10.1029/2011GL048869, 2011 b.

Paterson, M. P. and Spillane K. T.: Surface films and the production of sea-salt aerosol, Q. J. Roy. Meteor. Soc., 95, 526-534, 1969.

Penner, J. E.: Carbonaceous aerosols influencing atmospheric radiation: black and organic carbon, edited by: Charlson, R. J. and Heitzenberg, J., Aerosol Forcing of Climate, Wiley, New York, USA, 91-108, 1995.

Pósfai, M., Simonics, R., Li, J., Hobbs, P. V., and Buseck, P. R.: Individual aerosol particles from biomass burning in southern Africa: 1. Composition and size distributions of carbonaceous particles, J. Geophys. Res., 108, 8483, doi:10.1029/2002JD002291, 2003.

Pueschel, R. F. and Van Valin, C. C.: The mixed nature of laboratory produced aerosols from seawater, J. Rech. Atmos., 8, 601-610, 1974

Putaud, J. P., Van Dingenen, R., Mangoni, M., Virkkula, A., Raes, F., Maring, H., Prospero, J. M., Swietlicki, E., Berg, O. H., Hillamo, R., and Makela, T.: Chemical mass closure and assessment of the origin of the submicron aerosol in the marine boundary layer and the free troposphere at Tenerife during ACE-2, Tellus Series B - Chemical and Physical Meteorology, 52, 141-168, 2000.

Qian, J. and Mopper, K.: Automated high-performance, hightemperature combustion total organic carbon analyzer, Anal. Chem., 68, 3090-3097, 1996.

Quinn, P. K. and Bates, T. S.: The case against climate regulation via oceanic phytoplankton sulphur emissions, Nature, 480, 5156, doi:10.1038/nature10580, 2011.

Quinn, P. K., Bates, T. S., Coffman, D., Onasch, T. B., Worsnop, D., Baynard, T., de Gouw, J. A., Goldan, P. D., Kuster, W. C., Williams, E., Roberts, J. M., Lerner, B., Stohl, A., Pettersson, A., and Lovejoy, E. R.: Impacts of sources and aging on submicrometer aerosol properties in the marine boundary layer across the Gulf of Maine, J. Geophys. Res., 111, D23S36, doi:10.1029/2006JD007582, 2006.

Reimer, P. J., Brown, T. A., and Reimer, R. W.: Discussion: reporting and calibration of post-bomb ${ }^{14} \mathrm{C}$ data, Radiocarbon, 46, 1299-1304, 2004.

Rinaldi, M., Facchini, M. C., Decesari, S., Carbone, C., Finessi, E., Mircea, M., Fuzzi, S., Ceburnis, D., Ehn, M., Kulmala, M., de Leeuw, G., and O'Dowd, C. D.: On the representativeness of coastal aerosol studies to open ocean studies: Mace Head - a case study, Atmos. Chem. Phys., 9, 9635-9646, doi:10.5194/acp-99635-2009, 2009.

Rinaldi, M., Decesari, S., Finessi, E., Giulianelli, L., Carbone, C., Fuzzi, S., O’Dowd, C. D., Ceburnis, D., and Facchini, M. C.: Primary and secondary organic marine aerosol and oceanic biological activity: Recent results and new perspectives for future studies, Adv. Meteorol., 2010, 310682, doi:10.1155/2010/310682, 2010.
Roelofs, G. J.: A GCM study of organic matter in marine aerosol and its potential contribution to cloud drop activation, Atmos. Chem. Phys., 8, 709-719, doi:10.5194/acp-8-709-2008, 2008.

Russell, L. M., Hawkins, L. N., Frossard, A. A., Quinn, P. K., and Bates, T. S.: Carbohydrate-like composition submicron atmospheric particles and their production from ocean bubble bursting, P. Natl. Acad. Sci. USA, 107, 6652-6657, doi:10.1073/pnas.0908905107, 2010.

Savoie, D. L., Arimoto, R., Keene, W. C., Prospero, J. M., Duce, R. A., and Galloway, J. N.: Marine biogenic and anthropogenic contributions to non-sea-salt sulfate in the marine boundary layer over the North Atlantic Ocean, J. Geophys. Res., 107, 4356, doi:10.1029/2001JD000970, 2002.

Schmitt-Kopplin, P., Liger-Belair, G., Koch, B. P., Flerus, R., Kattner, G., Harir, M., Kanawati, B., Lucio, M., Tziotis, D., Hertkorn, N., and Gebefügi, I.: Dissolved organic matter in sea spray: a transfer study from marine surface water to aerosols, Biogeosciences, 9, 1571-1582, doi:10.5194/bg-9-1571-2012, 2012.

Schnell, R. C.: Ice nuclei produced by laboratory cultured marine phytoplankton, Geophys. Res. Lett., 2, 500-502, doi:10.1029/GL002i011p00500, 1975.

Schnell, R. C. and Vali, G.: Freezing nuclei in marine waters, Tellus, 27, 321-23, 1975.

Sciare, J., Mihalopoulos, N., and Dentener, F. J.: Interannual variability of atmospheric dimethylsulfide in the Southern Indian Ocean, J. Geophys. Res., 105, 26369-26378, 2000.

Sciare, J., Favez, O., Sarda-Estève, R., Oikonomou, K., Cachier, H., and Kazan, V.: Long-term observations of carbonaceous aerosols in the Austral Ocean atmosphere: Evidence of a biogenic marine organic source, J. Geophys. Res., 114, D15302, doi:10.1029/2009JD011998, 2009.

Sellegri, K., O’Dowd, C. D., Yoon, Y. J, Jennings, S. G., and de Leeuw, G.: Surfactants and submicron sea spray generation, J. Geophys. Res., 111, D22215, doi:10.1029/2005JD006658, 2006.

Sellegri, K., Villani, P., Picard, D., Dupuy, R., O'Dowd, C., and Laj, P.: Role of the volatile fraction of submicron marine aerosol on its hygroscopic properties, Atmos. Res., 90, 272-277, doi:10.1016/j.atmosres.2008.04.004, 2008.

Shank, L. M., Howell, S., Clarke, A. D., Freitag, S., Brekhovskikh, V., Kapustin, V., McNaughton, C., Campos, T., and Wood, R.: Organic matter and non-refractory aerosol over the remote Southeast Pacific: oceanic and combustion sources, Atmos. Chem. Phys., 12, 557-576, doi:10.5194/acp-12-557-2012, 2012.

Shaw, G. E.: Bio-controlled thermostasis involving the sulfur cycle," Climatic Change, 5, 297-303, 1983.

Smoydzin, L. and von Glasow, R.: Do organic surface films on sea salt aerosols influence atmospheric chemistry? - a model study, Atmos. Chem. Phys., 7, 5555-5567, doi:10.5194/acp-75555-2007, 2007.

Spracklen, D. V., Arnold, S. R., Carslaw, K. S., Sciare, J., and Pio, C.: Globally significant oceanic source of organic carbon aerosol, Geophys. Res. Lett., 35, L12811, doi:10.1029/2008GL033359, 2008.

Spyres, G., Nimmo, M., Worsfold, P. J., and Achterberg, E. P.: Determination of dissolved organic carbon in seawater using high temperature catalytic oxidation techniques, Trends in Anal. Chem., 19, 498-506, 2000. 
Stuiver, M. and Polach, H. A.: Discussion: reporting of ${ }^{14} \mathrm{C}$ data, Radiocarbon, 19, 355-363, 1977.

Sumner, A. L. and Shepson, P. B.: Snowpack production of formaldehyde and its effect on the Arctic troposphere, Nature, 398, 230-233, 1999.

Swietlicki, E., Hansson, H.-C., Hämeri, K., Svenningsson, B., Massling, A., McFiggans, G., McMurry, P. H., Petäjä, T., Tunved, P., Gysel, M., Topping, D., Weingartner, E., Baltensperger, U., Rissler, J., Wiedensohler, A., and Kulmala, M.: Hygroscopic properties of sub-micrometer atmospheric aerosol particles measured with H-TDMA instruments in various environments - a review, Tellus B, 60, 432-469, 2008.

Tseng, R.-S., Viechnicki, J. T., Skop, R. A., and Brown, J. W.: Seato-air transfer of surface-active organic compounds by bursting bubbles, J. Geophys. Res., 97, 5201-5206, 1992.

Turekian, V. C., Macko, S. A., and Keene, W. C.: Concentrations, isotopic compositions, and sources of size-resolved, particulate organic carbon and oxalate in near-surface marine air at Bermuda during spring, J. Geophys. Res., 108, 4157, doi:10.1029/2002jd002053, 2003.

Twomey, S.: Comparison of constrained linear inversion and an iterative nonlinear algorithm applied to indirect estimation of particle-size distributions, J. Comput. Phys., 18, 188-200, 1975.

Tyree, C. A., Hellion, V. M., Alexandrova, O. A., and Allen, J. O.: Foam droplets generated from natural and artificial seawaters, J. Geophys. Res., 112, D12204, doi:10.1029/2006JD007729, 2007.

Vignati, E., Facchini, M. C., Rinaldi, M., Scannell, C., Ceburnis, D., Sciare, J., Kanakidou, M., Myriokefalitakis, S., Dentener, F., and O'Dowd, C. D.: Global scale emission and distribution of seaspray aerosol: sea-salt and organic enrichment, Atmos. Environ., 44, 670-677, 2010.

Wang, H. B. and Kawamura, K.: Stable carbon isotopic composition of low-molecular-weight dicarboxylic acids and ketoacids in remote marine aerosols, J. Geophys. Res.-Atmos., 111, D07304, doi:10.1029/2005JD006466, 2006.

Westervelt, D. M., Moore, R. H., Nenes, A., and Adams, P. J.: Effect of primary organic sea spray emissions on cloud condensation nuclei concentrations, Atmos. Chem. Phys., 12, 89-101, doi:10.5194/acp-12-89-2012, 2012.
Wurl, O., Wurl, E., Miller, L., Johnson, K., and Vagle, S.: Formation and global distribution of sea-surface microlayers, Biogeosciences, 8, 121-135, doi:10.5194/bg-8-121-2011, 2011.

Yassaa, N., Peeken, I., Zöllner, E., Bluhm, K., Arnold, S., Spracklen, D., and Williams, J.: Evidence for marine production of monoterpenes, Environ. Chem., 5, 391-401, doi:10.1071/EN08047, 2008.

Yoon, Y. J., Ceburnis, D., Cavalli, F., Jourdan, O., Putaud, J. P., Facchini, M. C., Decesari, S., Fuzzi, S., Sellegri, K., Jennings, S. G., and O'Dowd, C. D.: Seasonal characteristics of the physicochemical properties of North Atlantic marine atmospheric aerosols, J. Geophys. Res., 112, D04206, doi:10.1029/2005JD007044, 2007.

Zábori, J., Matisāns, M., Krejci, R., Nilsson, E. D., and Ström, J.: Artificial primary marine aerosol production: a laboratory study with varying water temperature, salinity, and succinic acid concentration, Atmos. Chem. Phys., 12, 10709-10724, doi:10.5194/acp-12-10709-2012, 2012.

Zhang, Q., Jimenez, J. L., Canagaratna, M. R., Allan, J. D., Coe, H., Ulbrich, I., Alfarra, M. R., Takami, A., Middlebrook, A. M., Sun, Y. L., Dzepina, K., Dunlea, E., Docherty, K., DeCarlo, P., Salcedo, D., Onasch, T. B., Jayne, J. T., Miyoshi, T., Shimono, A., Hatakeyama, N., Takegawa, N., Kondo, Y., Schneider, J., Drewnick, F., Weimer, S., Demerjian, K. L., Williams, P. I., Bower, K. N., Bahreini, R., Cottrell, L., Griffin, R. J., Rautianen, J., and Worsnop, D. R.: Ubiquity and dominance of oxygenated species in organic aerosols in anthropogenically influenced northern hemisphere mid-latitudes, Geophys. Res. Lett., 34, L13801, doi:10.1029/2007GL029979, 2007.

Zhou, X. and Mopper, K.: Photochemical production of low molecular weight carbonyl compounds in seawater and surface microlayer and their air-sea exchange, Marine Chemistry, 56, 201-214, 1997.

Zhou, X., Davis, A. J., Kieber, D. J., Keene, W. C., Maben, J. R., Maring, H., Dahl, E. E., Izaguirre, M. A., Sander, R., and Smoydzyn, L.: Photochemical production of hydroxyl radical and hydroperoxides in water extracts of nascent marine aerosols produced by bursting bubbles from Sargasso seawater, Geophys. Res. Lett., 35, L20803, doi:10.1029/2008GL035418, 2008. 